\title{
Modeling the Potential Productivity of Urban Agriculture and Its Impacts on Soil Quality Through Experimental Research on Scale-Appropriate Systems
}

\author{
John R. Taylor* \\ Department of Plant Sciences and Entomology, University of Rhode Island, Kingston, RI, United States
}

Urban agriculture could play a central role in local and regional food sovereignty in developed countries, but in many cities, a lack of space and competition with other land uses limit production. Options for meaningfully advancing food sovereignty goals include sustainable intensification of existing urban farms and gardens; (2)

OPEN ACCESS

Edited by:

Gaston Small,

University of St. Thomas,

United States

Reviewed by:

James David Ward

University of South Australia, Australia

Houston Wilson,

University of California, Riverside,

United States

Nicolas Jelinski,

University of Minnesota Twin Cities,

United States

*Correspondence: John R. Taylor

jr_taylor@uriedu

Specialty section:

This article was submitted to Agroecology and Ecosystem Services,

a section of the journal Frontiers in Sustainable Food Systems

Received: 05 February 2020 Accepted: 18 May 2020

Published: 07 July 2020

Citation:

Taylor JR (2020) Modeling the

Potential Productivity of Urban Agriculture and Its Impacts on Soil

Quality Through Experimental

Research on Scale-Appropriate Systems.

Front. Sustain. Food Syst. 4:89 doi: 10.3389/fsufs.2020.00089 expansion of production into interstitial and other underutilized spaces undevelopable for other purposes; and (3) expansion of production in protected environments. Observational studies suggest that-like smallholder agriculture in the Global South-urban home, community, and market gardens in the developed world can be highly productive-but often are not. Research on scale-appropriate systems and outreach to urban agriculturalists are needed to help them grow more food, more sustainably. This replicated, long-term trial is addressing this need-and a dearth of experimental, normative research on urban agriculture-by evaluating the yield performance and impact on soil quality of four different systems of small-scale food production in Rhode Island, the second most densely populated state in the United States and a potential model for the development of sustainable urban food systems. Systems are modeled on vernacular systems in Providence, $\mathrm{RI}$ and Chicago, $\mathrm{IL}$ and on the scholarly and gray literature on sustainable intensification. They differ in soil management practices and nutrient sources. Results from the first 3 years of data collection indicate all four systems can be highly productive, with varying tradeoffs in terms of their sustainability and impacts on soil quality. While total marketable food yields were relatively modest compared to those reported in the gray literature for biointensive agriculture-2.22-2.96 $\mathrm{kg} \mathrm{m}^{-2}$ averaged over three summer growing seasons compared to $4.64 \mathrm{~kg} \mathrm{~m}^{-2}$ for the "low end" of biointensive production-yields for individual crops generally exceeded-and often far exceeded-regional averages and, for most crops and systems, national averages, without a loss in soil quality. In addition to demonstrating the high productivity of small-scale systems compared to commercial farms, the study establishes a framework for conducting normative, experimental research that can help to guide practice. It also offers more reliable yield estimates for modeling the production potential of cities than do observational studies and agronomic experiments on monocultures.

Keywords: urban agriculture, sustainable intensification, ecosystem services, self-provisioning, urban food garden, home garden 


\section{INTRODUCTION}

Planners, academics, and food activists in developed countries increasingly recognize the potential role of urban to periurban agriculture in increasing local, state, and regional food sovereignty (Alkon and Mares, 2012; Heynen et al., 2012; Tornaghi, 2017). In the United States, New England's 50 by 60 plan, for example, calls for meeting $50 \%$ of food needs through regional production by the year 2060 (Donahue et al., 2014). The projected agricultural acreage required to meet this ambitious goal includes 20,000 acres of urban and 210,000 acres of suburban land (Donahue et al., 2014), much of it in the Northeast Megalopolis stretching from Washington, D.C., to Boston and sheltering $18 \%$ of the U.S. population on $2 \%$ of the land base (Yaro and Carbonell, 2018). While some U.S. cities, e.g., Oakland (McClintock et al., 2013), Chicago (Taylor and Lovell, 2012), and Detroit (Beniston and Lal, 2012) may have large expanses of vacant land due to cycles of investment and disinvestment, such land is relatively scarce in other urbanized and urbanizing regions-including New England, the site of this researchbecause of development pressure. The city of Providence, Rhode Island, for example, was estimated to have $\sim 476$ city-owned vacant lots in 2013 (Asen et al., 2014) compared to $~ 19,500$ cityowned parcels in Chicago (City of Chicago., 2020). Land-based urban production in more land-starved regions may be limited to fragmented interstitial and other underutilized spaces, including residential lots. Existing production at this scale appears already to make a far larger contribution to urban food systems than larger scale agroecosystems, such as urban farms (Taylor and Lovell, 2012).

Given constraints on land availability in many regions, options for meaningfully advancing food sovereignty goals through urban agriculture include: (1) intensifying production of existing farms and gardens; (2) expanding the acreage of existing production through dispersed, small to very small-scale home and market gardens and farms on already developed land, on residential lots and in interstitial and other unproductive, leftover spaces; and (3) expanding production in protected environments ranging from unheated greenhouses (high tunnels) to more technologically sophisticated-and resource-demanding-systems including hydroponic or aquaponic greenhouses and vertical farms. Except for the use of high tunnels, increasing local food production through the third option is unlikely to increase food sovereignty as defined by La Via Campesina: "the right of farmers, peasants to produce food and the right of consumers to be able to decide what they consume, and how and by whom it is produced" (Via Campesina, 2003). Protected production can be capital intensive, particularly when established in central business districts (Benke and Tomkins, 2017), and potentially concentrates control over the food system in yet fewer hands.

The value of urban agriculture at any scale lies in its multifunctionality (Lovell, 2010). Growing food in cities makes little social, economic, or environmental sense if the sole or even primary goal is production. Privileging production may, in fact, lead to ecosystem disservices, including reduced soil quality, nutrient loading of stormwater runoff, reduced noncrop plant diversity, and reduced vegetative structure leading to a reduction in ecological niches and, consequently, biodiversity at higher trophic levels (Dewaelheyns et al., 2014; Taylor and Lovell, 2015; Taylor et al., 2017). At the same time, the literature suggests that the productivity, safety, and sustainability of urban agriculture could be improved without sacrificing-or even with enhancing-its cultural and ecological functions through scale-appropriate, systems-based research, outreach to urban gardeners and farmers, and planning interventions designed to encourage small-scale production (Beck et al., 2001; Witzling et al., 2011; Hunter et al., 2020).

Unfortunately, agronomists, horticulturists, and other plant scientists have been largely absent from the scholarly discourse on urban agriculture, and experimental agronomic research that could inform sustainable food production practices in cities is thin despite repeated calls for such research (Wortman and Lovell, 2013; Taylor and Lovell, 2014, 2015; Wagstaff and Wortman, 2015). Fully replicated research on land-based, urbanscale production systems in the U.S. is limited to just four studies. Miernicki et al. (2018) conducted a 2-years, ex situ factorial experiment evaluating the impacts of different urban production systems on the yield of a limited number of crops (radish, kale, cilantro, pepper, and garlic) from very small plots $\left(1.5 \mathrm{~m}^{2}\right)$. Wagstaff and Wortman (2015) evaluated the performance of ten vegetable crops and measured variation in environmental variables at six sites, with replication, along an urban to periurban transect in metropolitan Chicago. Beniston et al. (2016) evaluated the impacts of diverse amendments on soil quality and the yield of three crops (tomato, chard, and sweet potato) in a replicated, in situ experiment conducted over a 2-years period in a small U.S. city, Youngstown, OH. Small et al. (2017) examined the effect of compost made from varying ratios of barley mash to woodchips on nutrient recycling efficiency and yield of two crops, arugula and tomato, in a raised bed system over a single growing season.

Much larger is the literature based on observational studies conducted by ecologists, entomologists, sociologists, geographers, and others. These studies have been productive in characterizing the social, economic, and environmental conditions of urban agriculture and the vernacular production systems that have developed in response to those conditions. Observational research indicates that land-based urban agriculture offers myriad challenges-and opportunities-which make it distinct from rural agriculture. Research on commercial production in monoculture-the focus of most programs at U.S. land grant universities-cannot simply be scaled down to an urban lot. Urban crops may be more light-limited than those grown in rural agroecosystems; shading from trees and adjacent buildings can reduce urban crop yields by up to $50 \%$ (Wagstaff and Wortman, 2015). Higher temperatures in cities (Pickett et al., 2011) may benefit some crop plant species but limit the productivity of others, while higher vapor pressure deficits can lead to drought stress and reduced photosynthesis (Wortman and Lovell, 2013). Air pollution may reduce yields, and use of pesticides may be limited due to proximity to residential areas (Wortman and Lovell, 2013). Highly heterogeneous in nature, urban garden soils are of variable quality and are often contaminated with heavy metals and organic compounds 
(Witzling et al., 2011; Taylor and Lovell, 2015) but may be less compacted than agricultural soils (Edmondson et al., 2011). Soil contamination may require the use of raised beds or a cap-and-fill system in which the entire lot is capped with a geotextile or an impermeable material followed by a layer of woodchips or gravel and then a layer of compost-loam mix. Mix depth can range from 12.5 to more than $38 \mathrm{~cm}$, and percent organic matter may exceed 30\% (more than seven times that of typical field soils) (Taylor and Lovell, unpublished data). These mixes add further complexity to the urban growing environment (Wortman and Lovell, 2013).

At a time when rural growers are increasingly using tools such as precision agriculture technology to improve nutrient use efficiency in field crops, nutrient management in land-based urban systems is relatively unsophisticated (Taylor and Lovell, 2015; Small et al., 2019). Regular soil testing and the use of organic fertilizers on urban farms appear to be rare, and the use of synthetic chemical fertilizers is undocumented (Moskal and Berthrong, 2018). Instead, growers apply pure compost to growing beds as frequently as once a year to attempt to meet the nitrogen requirements of crops and to "feed the soil" (Taylor and Lovell, 2015; Moskal and Berthrong, 2018). Depending on compost inputs, this practice may lead to the accumulation of excessive levels of some nutrients, such as phosphorus (Taylor and Lovell, 2015; Moskal and Berthrong, 2018; Small et al., 2019) but may not provide sufficient nitrogen for adequate crop yields. The range of nutrient management practices appears to be even greater among urban home gardeners. Some gardeners may apply water-soluble synthetic fertilizers one or more times a week, while others rely solely on bagged compost or manures to restore soil fertility (Taylor and Lovell, 2015; Small et al., 2019). The resulting excessively high levels of nitrogen and phosphorus in soils and media may create pollution hotspots in the urban environment (Small et al., 2019).

The cropping practices of urban growers also appear to differ significantly from those of rural producers, though data are scarce. Plots are small, and gardeners and farmers may be reluctant or unable to leave areas fallow to allow the soil to recover from intensive production, to rotate crops to break pest cycles, or to plant cover crops to reduce soil erosion and to improve soil quality. In home and community gardens, crops may be grown in mixed polycultures, with two or more crops growing in intimate association (Airriess and Clawson, 1994; Woods et al., 2016; Taylor et al., 2017). Even if crops are grown in single-species rows or blocks, plots represent polycultures compared to the scale of commercial field production, with many of the potential advantages and disadvantages of intercropping, including increased or decreased yields, reduced pest pressure, high knowledge demand, and increased labor (Lithourgidis et al., 2011; Yu et al., 2015).

While some have argued for the collection of yet more observational data on the productivity of urban agriculture for use in modeling current and potential production (Pollard et al., 2017), the value of devoting more resources to such efforts is questionable. Existing studies consistently indicate large variations in crop yields in the same city or region (Pollard et al., 2017). Variability in a single study may be due to one or, more likely, a combination of factors: participation in the study by gardeners with a wide range of experience, skill, and education; variation in environmental conditions (Ackerman, 2012); the sheer diversity of crops and production systems in possibly all but the most culturally homogeneous cities; and inconsistencies in data collection. Collecting representative data for even a single city demands large sample sizes and multi-year data collection, but existing studies fail to meet these criteria. Sample sizes are small due to participant burden and attrition, ranging from 10 to 50 final participants (Reeves et al., 2014; CoDyre et al., 2015; McDougall et al., 2019). Data collection periods are short, often spanning a single growing season but occasionally extending to up to 2 years.

The convenience samples on which observational studies are based may fail to represent important urban gardening groups. In some cities, immigrants make a substantial but often unrecognized contribution to home and community garden production (Taylor and Lovell, 2012, 2015; Buchthal et al., 2019). Language barriers may militate against their inclusion in study samples. The gardening population-at least in the United States-also skews older. The digital divide may result in lower participation rates for these gardeners if recruitment is primarily conducted through the Internet or if data collection requires access to or use of handheld digital devices and applications. In addition, data collection procedures are inconsistent across studies and are inadequately documented. It is often unclear whether the area of failed crops or unproductive garden spaces, e.g., paths between community garden plots or between production beds, are included in the calculation of average yields or whether production has been graded for quality, as it is in agronomic experiments. Researchers may also estimate crop yields for a large area based on selfreported yields from a very small sample of gardeners (Gittleman et al., 2012), potentially biasing and inflating estimates.

All of these factors undermine the reliability, representativeness, and general usefulness of data collected through observational research for modeling urban agricultural production capacity or informing practice. What are needed are not more observational studies documenting the successes and failures of existing production systems but the development and promulgation of normative systems of urban agriculture based on experimental evidence and a systems-based, adaptive approach to research.

This paper describes the first 3 years of a long-term trial of intensive vegetable production systems suitable for urban market production or home provisioning. These 3 years constituted the primary exploratory and learning phase of the trial. Practices including weed management, tillage, and fertilization and crop mix evolved over this period of the experiment, as the researcher developed more knowledge of the systems, and will continue to evolve. In this way, the trial reproduces the adaptive approach of beginning and experienced growers, who constantly revise, refine, and adapt their production systems based on ongoing observation of system dynamics.

The overall goal of the project is to evaluate, in a replicated experiment, the long-term, relative performance of four different systems of small-scale vegetable production appropriate to urban 
to peri-urban agriculture in the U.S. state of Rhode Island. As the second most densely populated state in the U.S., with a population density almost ten times that of the United States as a whole, Rhode Island offers a potential model for the development of sustainable food systems and the expansion of regional food sovereignty through urban agriculture in the Northeast and elsewhere. In addition to comparing system performance, the project is intended to provide insights into challenges and opportunities in small-scale food production, to generate hypotheses for future research on urban agricultural systems, and to provide management guidelines for production in similar systems for dissemination through the University of Rhode Island's Cooperative Extension Service. The trial also serves as a training site for undergraduate research fellows in the University of Rhode Island's Sustainable Agriculture and Food Systems Program and the Department of Plant Sciences and Entomology major.

The first 3 years of data collection-as reported in this paperfocused on system productivity (measured by crop yield and value) and changes in soil quality. In future years, the range of system variables tracked will be expanded to include water use, labor, soil microbial composition and diversity, and other measures of sustainability and ecosystem services.

\section{MATERIALS AND METHODS}

\section{Site and Soil}

The trial is being conducted at the University of Rhode Island's Gardner Crops Research Center, West Kingston, Rhode Island, USA (lat. $41^{\circ} 29^{\prime}$, long. $71^{\circ} 32^{\prime} \mathrm{W}$ ) $\sim 28 \mathrm{~km}$ SSW of the state capital, Providence. The site is $\sim 36 \mathrm{~m}$ above sea level. A small coastal state in southern New England, Rhode Island has a humid climate with a relatively even distribution of precipitation throughout the year and large seasonal variations in temperature (RI DEM, 2020). Weather data have been collected continuously at the Gardner Crops Research Center since 1931. The average annual precipitation for the past decade was $135.3 \mathrm{~cm}$, during which time the average maximum and minimum temperatures were $4.8^{\circ}$ and $-6.8^{\circ} \mathrm{C}$ in January and $29.5^{\circ}$ and $16.9^{\circ} \mathrm{C}$ in July. The average length of the frost-free growing season was 172 days, with the last spring frost occurring on May 13 and the first fall frost on October 17, on average.

Experimental plots were established in 2017 on an Enfield silt loam (coarse-silty over sandy or sandy-skeletal, mixed, active, mesic Typic Dystrudept) (NRCS, 2020). The majority of the site was fallow during the 2016 growing season, with a mixture of volunteer red clover and self-sown grasses. In early May 2017, the site was moldboard plowed and then disked twice. The trial employs a randomized complete block design with 4 replicates; each plot measures $6.4 \times 15.24 \mathrm{~m}(21 \times 50 \mathrm{ft})$ and is subdivided into 6 growing beds, $0.76 \times 15.24 \mathrm{~m}(2.5 \times 50 \mathrm{ft})$, separated by a path $0.30 \mathrm{~m}(1 \mathrm{ft})$ in width. Bed width is typical for small-scale intensive systems (Fortier and Bilodeau, 2014; Coleman, 2018); path width is somewhat narrower than that recommended in the gray literature but minimizes unproductive space while still permitting movement through the plot.

\section{Production Systems}

The four systems evaluated were initially modeled on practices observed by the author during research on urban gardens and farms in Chicago, Illinois, and Providence, Rhode Island. System design also drew on the scholarly literature on urban agriculture, sustainable agriculture and agroecological practice (Wezel et al., 2014; Garbach et al., 2017) and on the gray literature on smallscale intensive vegetable production (Fortier and Bilodeau, 2014; Coleman, 2018). The systems differ in soil management practices and nutrient sources but all employ a permanent bed design, rely on only pesticides approved by the Organic Materials Institute (OMRI) for the control of insects and fungal diseases, have no fallow period, incorporate cover crops when practicable, rotate the same suite of crops at the same planting densities on an identical rotation schedule, and irrigate with drip tape. While these system characteristics are fixed, others are allowed to change over time in keeping with the adaptive management philosophy of the trial. Pest management, tillage, and fertilization and crop mix evolved over the initial learning phase of the experiment described in this article, as the researcher developed more knowledge of the systems.

\section{System Descriptions Conventional}

This system features synthetic fertilizers and conventional tillage with a rototiller. Solid fertilizer is incorporated into the soil prior to planting, and additional, water-soluble nitrogen (urea) is applied during the growing season, per the cropspecific recommendations found in the New England Vegetable Management Guide, a collaborative effort of Cooperative Extension vegetable programs in the six New England states (Campbell-Nelson, 2020). The conventional system, which serves as the control, reproduces the production practices that an agricultural extension agent might recommend to a conventional, small-scale market gardener or to a home gardener based on the research literature. The synthetic fertilizers used in this system have several advantages from a production standpoint; they are easily procured, are very inexpensive compared to other nutrient sources, act quickly, and require very little labor to apply, unlike compost. Compared to other machines for small-scale gardening and farming such as walk-behind tractors, rototillers are relatively inexpensive. Even urban home gardeners may own and use a rototiller. In the United States, rototillers can also be rented from various outlets on an hourly or daily basis.

\section{Precision organic}

This system differs from the conventional system in relying on minimal tillage (to a depth of $7.6 \mathrm{~cm}$ with a rotary power harrow) for bed preparation and OMRI-approved fertilizers as a nutrient source. Solid fertilizers are applied per the initial application rates prescribed in the New England Vegetable Management Guide. Though bulkier, solid organic fertilizers are, like synthetic fertilizers, easy to procure and to apply but are typically much more expensive than synthetic fertilizers and, because they require mineralization by soil microorganisms, slower-acting (and consequently less vulnerable to leaching). To reduce subsequent nutrient input costs and to tailor nitrogen 
inputs to plant needs, the application of additional (watersoluble) OMRI-approved fertilizer is scheduled based on the evaluation of crop nitrogen status during the growing season using a Minolta SPAD-502 chlorophyll meter (Konica Minolta, Inc., Tokyo, Japan). While use of such a meter would not be cost effective for small scale growers, lower cost alternatives such as the atLEAF chlorophyll meter (FT Green LLC, Wilmington, DE, USA) could be.

\section{Compost-only}

This system seeks to minimize inputs from outside Rhode Island and to close open nutrient loops. It is modeled on organic market gardening and community gardening practices and has transitioned from full tillage (2016) to deep tillage (broadforking in 2018) to no-till (2019). Local, organic-approved yard waste compost from the Rhode Island Resource Recovery Center (RIRRC) in Johnston, RI serves as the primary source of nutrients, with additional, regionally-sourced, OMRI-approved water-soluble fertilizer applied at the time of transplanting. Each year, compost has been surface applied by volume at a rate of $0.29 \mathrm{~m}^{3}$ per $0.76 \times 15.24 \mathrm{~m}$ bed, which is comparable to the annual application rate recommended by the Southside Community Land Trust (A. Cook, personal communication), Rhode Island's largest urban agriculture service provider, to community gardeners and growers and by Fortier and Bilodeau (Fortier and Bilodeau, 2014) to market gardeners.

\section{Urban cap-and-fill}

(Figure 1). This system is modeled on practices for mitigating urban soil contamination. In the absence of any published recommendations or best management practices for such systems, system specifications were developed based on observations of urban farms in Chicago and Providence. Each plot was covered with a woven geotextile fabric meeting American Society for Testing and Materials (ASTM) standards specified for contaminant mitigation on urban agriculture sites by the Boston Public Health Commission (Boston Public Health Commission, 2013). On top of this cap, $0.76 \mathrm{~m}$ wide and $0.38 \mathrm{~m}$ high windrows of a 50:50 mix of RIRRC compost and loam were shaped by tractor and by hand to create planting beds. The narrow, $0.30 \mathrm{~m}$ wide swales between windrows were filled with woodchips from University of Rhode Island campus sources to create paths almost level with the tops of the planting beds. Each year, OMRI-approved water-soluble fertilizer is applied at the time of transplanting.

\section{Nutrient Inputs}

A fertilizer solution was applied at the time of planting to transplants in all four systems at a rate of $9.4 \mathrm{~kg}$ of $\mathrm{P}$ $\mathrm{ha}^{-1}$. Jack's 9-45-15 water soluble fertilizer (JR Peters, Inc., Allentown, PA, USA) was applied to crops in the conventional plots. Neptune's Harvest Tomato and Vegetable Formula 2-42 (Neptune's Harvest, Gloucester, MA, USA) was applied to crops in the precision organic, urban cap-and-fill, and compostonly systems. No additional fertilizer was applied to the urban cap-and-fill or compost-only plots.

Pre-plant fertilizers were applied to the conventional and precision organic plots at the crop-specific rates recommended in the New England Vegetable Management Guide. Granular, synthetic 19-19-19 or 23-12-18-depending on the phosphorus needs of the crop-was applied to the conventional beds prior to rototilling. Pro-Gro 5-3-4 (North Country Organics, Bradford, VT, USA) was applied to the precision organic plots prior to harrowing. Crops in the conventional plots were sidedressed with urea (46-0-0) at the times and rates recommended in the management guide.

Sidedressing-with a water-soluble, OMRI-approved fertilizer (Alaska 5-1-1 Liquid Fish Fertilizer, Pennington Seed, Inc., Madison, GA, USA)-was adaptive and crop dependent in the precision organic plots. Prior to sidedressing, the nitrogen status of the 5 core vegetable crops (tomato, eggplant, zucchini, chard, and kale) was evaluated using a Minolta SPAD-502 chlorophyll meter. In each crop subplot, SPAD readings were taken for the youngest fully mature leaf from 7 randomly selected plants and averaged. If the average was $<95 \%$ of the reference value for the crop, the subplot was fertilized at a rate of $28 \mathrm{~kg} \mathrm{ha}^{-1}$. Reference values were derived from plantings of the core crops established in an adjacent reference plot. Each crop was represented in the plot by 7 plants, which were fertilized at a rate equal to $120 \%$ of the total nitrogen rate recommended for the crop in the New England Vegetable Management Guide. Reference values for each crop were calculated using the same sampling method used to determine the nitrogen status of crops in the precision organic plots. Other crops were sidedressed at the rates and according to the schedule described in the management guide.

\section{Weed Management}

In 2017, three warm-season, transplanted crops-tomato, eggplant, and zucchini-were grown in black plastic mulch in the control, precision organic, and compost-only systems. Other crops remained unmulched and were weeded by hand or by hoe. In 2018 and 2019, a reusable woven weed barrier (DeWitt

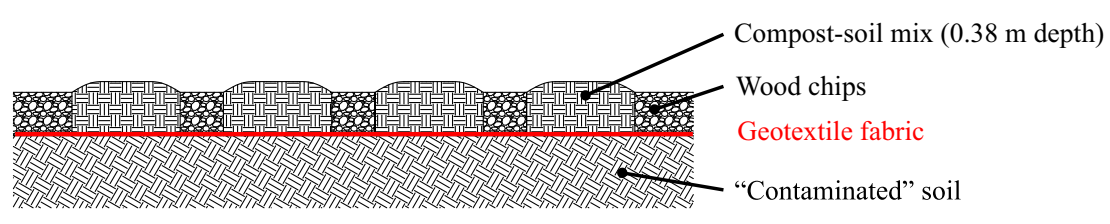

FIGURE 1 | Urban cap-and-fill system. 
SBLT4300 Sunbelt Ground Cover Weed Barrier, DeWitt Co., Sikeston, MO, USA) was used for these three crops plus melon and basil (2018) and basil, sweet potato, and acorn squash (2019) in the control and precision organic systems. Use of plastic mulch was discontinued in the compost-only system after 2017 to reduce dependence on external inputs and, potentially, to allow for intercropping. No plastic mulches were used in the urban cap-and-fill system during the study period, following practices observed on urban farms in Chicago and Providence.

\section{Irrigation}

All crops were irrigated using drip tape (Aquatraxx, Toro Co., Bloomington, MN) with two emitter lines per bed. Tape with an emitter spacing of $30.5 \mathrm{~cm}$ (12 in) was used in 2017 and 2018; spacing was reduced to $15.2 \mathrm{~cm}$ (6 in) in 2019 for better coverage of planting beds. Irrigation was scheduled using the feel and appearance method (NRCS, 1998), since this was deemed to be the most accessible method for urban growers for scheduling irrigation. Irrigation water was sourced from the University of Rhode Island Water System, which draws from three high volume wells fed by an aquifer that extends beneath the study site. The water is chlorinated and potable. The volume of water applied to each plot was not tracked during the study period.

\section{Cover Cropping}

Cover cropping is relatively infrequent in urban gardens in the author's experience and others' (Gregory et al., 2016) but could have a positive impact on soil quality while reducing erosion, scavenging nutrients at the end of the growing season, and, if leguminous crops are used, offsetting external inputs of nitrogen for subsequent food crops (Gregory, 2017). At the end of the 2017 and 2018 growing seasons, half of the beds in each systemcorresponding to the same crops the following growing seasonwere cover cropped with cereal rye, sown at a rate of $90 \mathrm{~kg}$ $\mathrm{ha}^{-1}$ the first week in October. The cover crop was terminated in the spring at the soft dough stage by mowing followed by occultation with a black plastic tarp following Fortier and Bilodeau (2014). Conventional and precision organic plots were tilled after occultation. All vegetable beds in each experimental plot were cover cropped with rye in October 2019.

\section{Crop Assemblages}

Crops were selected based on their popularity, relative ease of cultivation, and nutritional value. The crop mix became increasingly diverse over the 3 -years period, expanding from six crops in 2017 to 20 in 2019 (Table 1). Five core crops-eggplant (Solanum melongena "Orient Express"), tomato (Lycopersicon esculentum "Mt. Fresh Plus"), zucchini (Cucurbita pepo "Raven”), chard (Beta vulgaris subsp. vulgaris "Bright Lights"), and kale (Brassica oleracea "Toscano")-were planted each season to support comparisons of yields across all 3 years of the study. Cut flowers-zinnia (Zinnia elegans "Benary's Giant") and rudbeckia (Rudbeckia hirta "Indian Summer") - were added to the crop mix in 2018 because they can be a profitable crop for market gardeners, support pollinators, and improve plot aesthetics, a potentially important function in urban environments, where food production may be perceived to be transgressive. By 2019,
TABLE 1 | Crop assemblages, 2017-2019.

\begin{tabular}{|c|c|c|}
\hline 2017 & 2018 & 2019 \\
\hline $\begin{array}{l}\text { Chard (Beta vulgaris } \\
\text { subsp. vulgaris) } \\
\text { "Bright Lights" } \\
\text { Edamame (Glycine } \\
\text { soja) "Tohya" } \\
\text { Eggplant (Solanum } \\
\text { melongena) "Orient } \\
\text { Express" } \\
\text { Kale (Brassica } \\
\text { oleracea) "Toscano" } \\
\text { Tomato } \\
\text { (Lycopersicon } \\
\text { esculentum) } \\
\text { "Mountain Fresh } \\
\text { Plus" } \\
\text { Zucchini (Cucurbita } \\
\text { pepo) "Raven" }\end{array}$ & $\begin{array}{l}\text { Basil (Ocimium basilicum) } \\
\text { "Genovese" } \\
\text { Cabbage (Brassica } \\
\text { oleracea) "Tiara" } \\
\text { Chard (Beta vulgaris } \\
\text { subsp. vulgaris) "Bright } \\
\text { Lights" } \\
\text { Dry bean (Phaseolus } \\
\text { vulgaris) "Maine Sunset" } \\
\text { Eggplant (Solanum } \\
\text { melongena) "Orient } \\
\text { Express" } \\
\text { Kale (Brassica } \\
\text { oleracea) "Toscano" } \\
\text { Melon (Cucumis melo) } \\
\text { "Savor" } \\
\text { Pepper (Capsicum } \\
\text { anuum) "Ace" } \\
\text { Rudbeckia (Rudbeckia } \\
\text { hirta) "Indian Summer" } \\
\text { Tomato (Lycopersicon } \\
\text { esculentum) "Mountain } \\
\text { Fresh Plus" } \\
\text { Zinnia (Zinnia elegans) } \\
\text { "Benary"s Giant" } \\
\text { Zucchini (Cucurbita } \\
\text { pepo) "Raven" }\end{array}$ & $\begin{array}{l}\text { Acorn squash (Cucurbita } \\
\text { pepo) "Table Gold" } \\
\text { Basil (Ocimium basilicum) } \\
\text { "Genovese" } \\
\text { Cabbage (Brassica } \\
\text { oleracea) "Tiara" } \\
\text { Chard (Beta vulgaris } \\
\text { subsp. vulgaris) "Bright } \\
\text { Lights" } \\
\text { Chinese cabbage } \\
\text { (Brassica rapa var. } \\
\text { pekinensis) "Minuet" } \\
\text { Delphinium (Delphinium } \\
\text { elatum) "Magic Fountains } \\
\text { Mix" } \\
\text { Edamame (Glycine soja) } \\
\text { "Tohya" } \\
\text { Eggplant (Solanum } \\
\text { melongena) "Orient } \\
\text { Express" } \\
\text { Green bean (Phaseolus } \\
\text { vulgaris) "Jade" } \\
\text { Kale (Brassica } \\
\text { oleracea) "Toscano" } \\
\text { Lupine (Lupinus hybrid) } \\
\text { "Tutti Frutti" } \\
\text { Pepper (Capsicum } \\
\text { anuum) "Ace" } \\
\text { Purple coneflower } \\
\text { (Echinacea hybrid) } \\
\text { "Cheyenne Spirit" } \\
\text { Rudbeckia (Rudbeckia } \\
\text { hirta) "Indian Summer" } \\
\text { Sweet potato (Ipomoea } \\
\text { batatas) "Covington" } \\
\text { Tomato (Lycopersicon } \\
\text { esculentum) "Mountain } \\
\text { Fresh Plus" } \\
\text { Tomato (Lycopersicon } \\
\text { esculentum) "New Girl" } \\
\text { Tomato (Lycopersicon } \\
\text { esculentum) "Polbig" } \\
\text { Zinnia (Zinnia elegans) } \\
\text { "Benary's Giant" } \\
\text { Zucchini (Cucurbita } \\
\text { pepo) "Raven" }\end{array}$ \\
\hline
\end{tabular}

Core crops planted every year are in boldface.

a final 3-years vegetable crop rotation was established (Table 1). Of the six $0.76 \times 15.24 \mathrm{~m}$ beds, five are dedicated to vegetable production. Each bed is divided into three subplots, yielding a three-by-five grid of $15-0.76 \times 5.08 \mathrm{~m}$ subplots. The sixth bed, divided into five $0.76 \times 3.05$ subplots, is dedicated to cut flower production. In 2019, three perennial cut flowerspurple coneflower (Echinacea "Cheyenne Spirit"), delphinium (Delphinium elata "Magic Fountains Mix") and lupine (Lupinus "Tutti Frutti") - were added to the crop assemblage but will not contribute to production until 2020. To maximize comparability with 2018 data, the area of these 3 subplots was subtracted from the total plot area when total value of food and flower crops was 
calculated for 2019. The opportunity cost associated with the loss of production from the subplots will be taken into account in future economic analyses.

Vegetable crops are graded for marketability according to the United States Department of Agriculture's grade standards for the specific crop (Agricultural Marketing Service, 2005). Crops meeting the criteria for U.S. No. 2 or Commercial and higher grades are considered to be marketable. Flower crops are graded according to their appearance, including freedom from pest damage and deformity. Yield per square meter is calculated based on bed width $(0.76 \mathrm{~m})$ plus the width of the interbed space $(0.30 \mathrm{~m})$. It does not include alleys between research plots. This method of calculating yield is comparable to that used by the United States Department of Agriculture's vegetable surveys, which collect data from growers on harvested acreage and yield for each crop at the farm level (NASS, 2019). Nonproductive areas outside production fields are not included in the denominator when calculating yield per area. Interbed or interrow spaces within fields are.

\section{Soil Sampling and Analysis}

Baseline soil samples were collected from each plot in May 2017, after initial field preparation (with a moldboard plow and disk) and plot layout but before the application of fertilizer or compost. A total of 10 cores $15 \mathrm{~cm}$ in length were collected in a grid with a $2.22 \mathrm{~cm}$ diameter AMS soil probe (AMS Inc., American Falls, ID, USA) and composited to create a single sample per plot. In May and October of 2018 and 2019, a total of 18 subsamples-three $15 \mathrm{~cm}$ cores per bed-were collected from each plot and composited. All composited soil samples were air dried, sieved to $<2 \mathrm{~mm}$ and sent to Brookside Laboratories in New Bremen, $\mathrm{OH}$, USA and analyzed for: percent organic matter through loss on ignition at 360 degrees C (Schulte and Hopkins, 1996); $\mathrm{pH}$ with a 1:1 water dilution method (McLean, 1982); cation exchange capacity (Ross and Ketterings, 2011); potassium, phosphorus, manganese, zinc, boron, copper, iron, aluminum, calcium, magnesium, and sodium with a Mehlich-III extraction (Mehlich, 1984); and estimated nitrogen release based on percent organic matter. The October 2019 samples were also analyzed for permanganate oxidizable carbon, a measure of biologically active carbon (Weil et al., 2003), and bulk density. To estimate bulk density, the composite sample from each plot was ovendried at $105^{\circ} \mathrm{C}$ for $48 \mathrm{~h}$ then weighed. Bulk density was calculated by dividing the oven-dry weight ( $\mathrm{g}$ ) of each sample by the total volume of the 18 cores constituting the sample.

A double-ring infiltrometer (Turf-tec International Tallahassee, FL, USA) was used in October 2019 in a randomly selected location in each experimental plot to determine the rate of water infiltration. Both inner and outer rings of the infiltrometer were filled with water, allowed to drain, and then immediately refilled. The decline in the level of water in the inner ring over a ten-minute period was measured.

\section{Statistical Analysis}

Based on marketable yield data, summary variables (total food yield, total food value, and total value of food and flower production) were calculated for each plot. Crop value was determined based on unit prices collected from a local farmer's market and a local grocery store in summer and fall 2019. Data for summary variables, individual crop yields, and soil physical properties were analyzed by GLIMMIX procedure in SAS University Edition software (SAS Institute Inc., Cary, NC, USA). Treatment, year, and their interaction were treated as fixed effects, and replication was a random effect. If there was no interaction between treatment and year, data were pooled across years. Prior to all analyses, data were evaluated for normality and homogeneity of variance by UNIVARIATE procedure in the software and ln-, cube-, or square root-transformed, if necessary, with back-transformed values for means reported in the text and tables. Dunnett's test was used to determine differences between the least squares means of the three experimental treatments (compost-only, precision organic, and urban cap-and-fill) and the control treatment (conventional) at a significance level of $\alpha=0.05$ for summary variables and individual crop yields. The Tukey-Kramer multiple comparisons tests was used to separate means for soil chemical properties in 2017 and soil chemical and physical properties in 2019. Differences in soil chemical properties between spring 2017 and fall 2019 for each treatment were evaluated using the TTEST procedure in the SAS software. To compare soil properties across treatment plots, non-metric dimensional scaling (NMDS) ordinations of plots were performed (PROC NMDS in the SAS software) using BrayCurtis dissimilarity matrices for 2017 and 2019 soil data.

\section{RESULTS \\ Productivity}

Pooled across the 3 years of the study, average marketable food yield was significantly lower only for the compost-only treatment $\left(2.22 \mathrm{~kg} \mathrm{~m}^{-2}\right)$ compared to the conventional (control) treatment $\left(2.96 \mathrm{~kg} \mathrm{~m}^{-2}\right)$; yields in the precision organic $\left(2.87 \mathrm{~kg} \mathrm{~m}^{-2}\right)$ and urban cap-and-fill $\left(2.61 \mathrm{~kg} \mathrm{~m}^{-2}\right)$ treatments did not differ significantly from the average yield of the conventional treatment (Table 2). For all treatments, yields declined from 2017 to 2018 and then increased from 2018 to 2019. Yield loss from 2017 to 2018 was greatest in the in-ground treatments, ranging from $25.1 \%$ (conventional) to $39.8 \%$ (compost-only), and smallest in the urban cap-and-fill treatment (9.6\%).

The compost-only treatment yielded significantly less than the conventional treatment in 2017 and 2018, as did the urban capand-fill treatment in 2017. Yields did not differ from the control for any of the other treatments during the 3-years period. Average marketable food yield for the compost-only treatment increased $86 \%$ between 2018 and 2019, from 1.47 to $2.74 \mathrm{~kg} \mathrm{~m}^{-2}$, and was not significantly different from average yield for the control in 2019.

Yields for individual core crops grown every year of the study did not necessarily track year-to-year changes in total food yield (Tables 3, 4). Yields of the highest yielding crop on a weight per square meter basis, tomato "Mt. Fresh Plus," declined for all three in-ground treatments from 2017 to 2018, from 41.8\% (compost-only) to $44.0 \%$ (precision organic); average yield was almost unchanged for the urban cap-and-fill treatment. Yields rebounded in 2019 for the compost-only and precision organic 
TABLE 2 | Marketable system yield and value of system production by year and pooled across years when the treatment-by-year interaction was not significant ( $p>0.05$ ).

\begin{tabular}{|c|c|c|c|c|c|c|c|c|c|c|}
\hline \multirow[t]{2}{*}{ Treatment } & \multirow{2}{*}{\multicolumn{4}{|c|}{$\begin{array}{l}\text { Marketable food yield } \\
\qquad \mathrm{kg} / \mathrm{m}^{3}\end{array}$}} & \multirow{2}{*}{\multicolumn{4}{|c|}{$\begin{array}{c}\text { Marketable food value } \\
\qquad \text { USD } / \mathrm{m}^{3}\end{array}$}} & \multirow{2}{*}{\multicolumn{2}{|c|}{$\begin{array}{c}\text { Total value of food }+ \\
\text { flower production } \\
\text { USD } / \mathrm{m}^{3}\end{array}$}} \\
\hline & & & & & & & & & & \\
\hline Conventional & 3.35 & 2.51 & 3.01 & 2.96 & 16.65 & 13.50 & 15.85 & 15.33 & 16.70 & 17.34 \\
\hline Compost-only & $2.44^{*}$ & $1.47^{\star}$ & 2.74 & $2.22^{\star}$ & $12.11^{*}$ & $7.94^{\star}$ & 15.00 & $11.68^{*}$ & $9.90^{*}$ & 16.67 \\
\hline SE & 0.18 & 0.12 & 0.16 & 0.19 & 0.87 & 0.56 & 0.89 & 0.88 & 0.91 & 0.95 \\
\hline
\end{tabular}

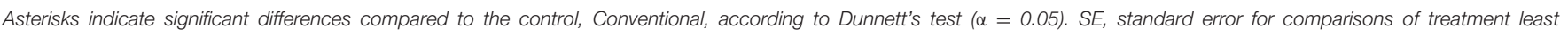
squares means.

TABLE 3 | Marketable yields by year for three core crops with a significant $(p<0.05)$ treatment-by-year interaction.

\begin{tabular}{|c|c|c|c|c|c|c|c|c|c|}
\hline \multirow[t]{2}{*}{ Treatment } & \multicolumn{3}{|c|}{$\begin{array}{l}\text { Eggplant "Orient Express" } \\
\qquad \mathrm{kg} / \mathrm{m}^{3}\end{array}$} & \multicolumn{3}{|c|}{$\begin{array}{c}\text { Chard "Bright Lights" } \\
\mathrm{kg} / \mathrm{m}^{3}\end{array}$} & \multicolumn{3}{|c|}{$\begin{array}{l}\text { Tomato "Mt. Fresh Plus" } \\
\qquad \mathrm{kg} / \mathrm{m}^{3}\end{array}$} \\
\hline & 2017 & 2018 & 2019 & 2017 & 2018 & 2019 & 2017 & 2018 & 2019 \\
\hline Conventional & 1.12 & 2.15 & 4.96 & 4.00 & 3.30 & 3.31 & 8.91 & 5.00 & 4.24 \\
\hline Compost-only & 0.71 & $0.67^{\star}$ & $1.98^{*}$ & $2.38^{\star}$ & $1.56^{\star}$ & 6.20 & $6.31^{*}$ & 3.67 & 5.86 \\
\hline Precision organic & 1.20 & 1.71 & 3.11 & 3.27 & 2.71 & 4.64 & 8.75 & 4.90 & $6.51^{*}$ \\
\hline
\end{tabular}

**Data were In transformed for normality and backtransformed for presentation of means, but standard errors cannot be backtransformed.

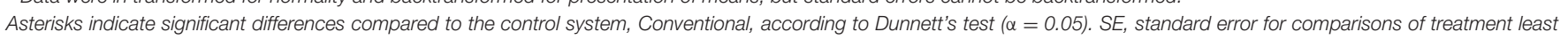
squares means.

plots-but not the conventional plots-despite the negative impact of early blight on the tomato crop in 2019. In 2019, average tomato yield was significantly higher than the control for both the precision organic and urban cap-and-fill treatments and no different for the compost-only treatment. Unlike tomato yields, eggplant yields consistently increased across all treatments from 2017 to 2019 (with the exception of the compost-only treatment between 2017 and 2018), by as much as $343 \%$ in the case of the conventional treatment. Tracking total food yields, kale yields declined in all treatments from 2017 to 2018 and then increased in 2019. Chard and zucchini yields showed more complex patterns across the 3 years. When pooled, zucchini yields were significantly lower in the compost-only and urban cap-and-fill systems than in the conventional system. Across all treatments, average yields for individual crops grown for two or more years far exceeded 2016-2018 average yields reported for New England (USDA, 2019) and met or exceeded "good" yields based on national averages (Campbell-Nelson, 2020) for every crop in every treatment, with the exception of zucchini and eggplant (Figure 2).

Total food value was significantly lower than the control for the compost-only treatment in 2017 and 2018-but not 2019 - and when pooled across the three reporting years. It was not significantly different in 2019 (Table 2). Total food value was not significantly different from the control for any of the other three treatments, for individual years or when pooled except for the urban cap-and-fill treatment in 2017. Flower production (zinnias and rudbeckia) had a large positive impact on total production value at the system level across all four treatments, increasing average value per square meter in 2018 by $23.7 \%$ to $26.2 \%$ and in 2019 by $7.1 \%$ to $13.8 \%$ despite the relatively small harvested area in each plot in each year $\left(10.8 \mathrm{~m}^{2}\right.$ in 2018 and 6.5 $\mathrm{m}^{2}$ in 2019 , corresponding to $11.1 \%$ of total plot area in 2018 and $7.4 \%$ in 2019). Total flower production as measured by number of stems in the compost-only system was significantly lower than the control in 2018 and 2019. Flower production was not significantly different from the control in either of the other two systems in either year.

\section{Soil Quality}

In the base year, 2017, soil chemical properties prior to fertilization or compost application did not differ significantly by in-ground treatment, indicating that blocking was effective for controlling variations in soil characteristics across the experimental plots (Table 5). Reflecting the site's long history of agricultural management as part of the experiment station, phosphorus levels were relatively high, averaging $114-122 \mathrm{mg} \mathrm{kg}^{-1}$.

Soil chemical properties subsequently diverged by system type over the 3-years study period. Change was, of course, most rapid for the urban-cap-and fill plots, in which a premade 50:50 mix, by volume, of yard waste compost and offsite topsoil was placed over a geotextile cap over the native soil, reproducing a common soil remediation technique in urban agriculture. 
TABLE 4 | Marketable yields for two core crops by year and pooled across years due to an insignificant $(\rho>0.05)$ treatment-by-year interaction.

\begin{tabular}{|c|c|c|c|c|c|c|c|c|}
\hline \multirow[t]{2}{*}{ Treatment } & \multicolumn{4}{|c|}{$\begin{array}{c}\text { Kale "Toscano" } \\
\text { kg/m }\end{array}$} & \multicolumn{4}{|c|}{$\begin{array}{c}\text { Zucchini "Raven" } \\
\text { kg/m }\end{array}$} \\
\hline & 2017 & 2018 & 2019 & Ave. & 2017 & 2018 & 2019 & Ave. \\
\hline Conventional & 4.67 & 3.34 & 4.30 & 4.10 & 2.58 & 3.26 & 2.56 & 2.80 \\
\hline Compost-only & 3.28 & 2.68 & 3.66 & $3.21^{*}$ & 2.31 & $2.30^{\star}$ & $1.14^{*}$ & $1.92^{*}$ \\
\hline Precision organic & 4.53 & 3.09 & 3.82 & 3.81 & 2.61 & 2.95 & 2.02 & 2.52 \\
\hline Urban cap-and-fill & 4.97 & 3.24 & 3.82 & 4.01 & 1.76 & 3.03 & $0.85^{\star}$ & $1.88^{\star}$ \\
\hline SE & 0.56 & 0.34 & 0.39 & 0.34 & 0.55 & 0.28 & 0.29 & 0.31 \\
\hline
\end{tabular}

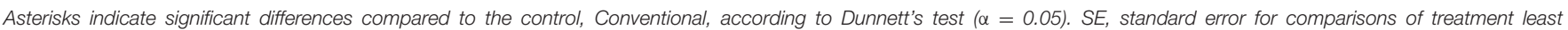
squares means.

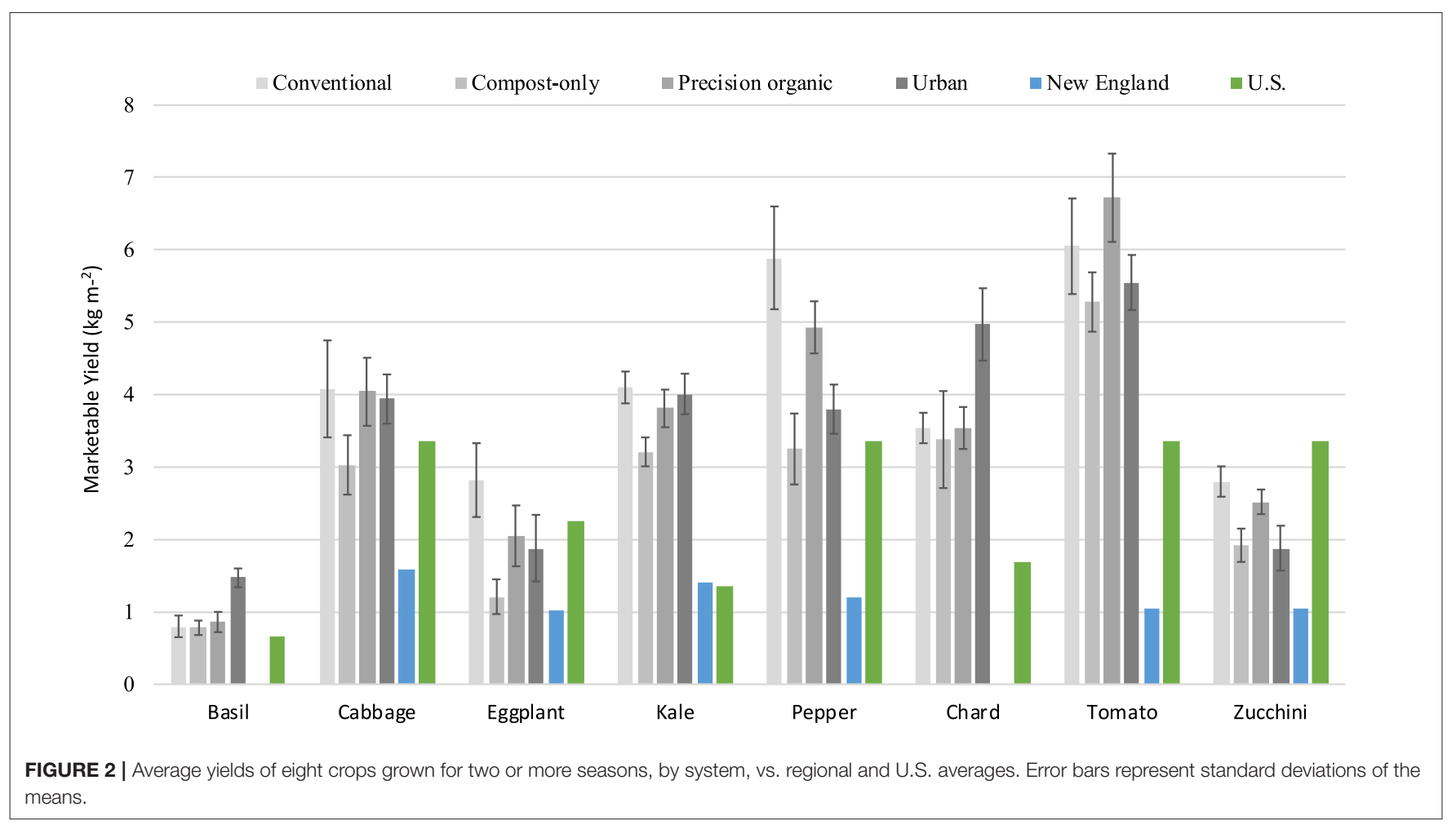

Chemical properties of the 50:50 compost-soil mix reflected the combined properties of the mix's constituents (Table 6). On average, all soil chemical characteristics but $\mathrm{pH}$ were significantly higher in the urban plots compared to all other treatments at baseline (Table 5). The organic matter content of the urban mix averaged $9.18 \%$ compared to $3.45-3.81 \%$ for the in-ground treatments prior to fertilization or compost application in 2017, with an estimated rate of nitrogen release of $134 \mathrm{~kg} \mathrm{ha}^{-1}$. Other plant macronutrients were present to excess in the urban treatment. Levels of phosphorus, a potential environmental pollutant, were more than twice as high, on average, than the already high levels found in the mineral soils of the in-ground treatments, and potassium levels in the urban plots averaged more than four times the levels found in the in-ground plots. Levels of sulfur, calcium, and magnesium were all, on average, two to three times higher for the urban treatment.
Nonmetric multidimensional scaling (NMDS) was used to visualize differences between plots based on soil chemical characteristics. NMDS facilitates visualization by representing the relationships between plots in a reduced number of dimensions (axes). Plot ordination was based on a BrayCurtis dissimilarity matrix based on soil chemical characteristics (CEC, pH, OM, P, K, S, Ca, Mg, Na, Fe, Mn, $\mathrm{Cu}, \mathrm{Zn}$, and $\mathrm{Al})$. The badness of fit criterion for each NMDS (0.009546 for the 2017 ordination and 0.005114 for 2019) indicates that the data fit the model extremely well. In the 2017 NMDS, the urban cap-and-fill plots cluster separately from the inground plots in ordination space based on these characteristics (Figure 3). In the 2019 NMDS, the compost-only plots cluster more closely with the urban cap-and-fill plots than with the other in-ground plots, indicating that the soils of the compostonly plots are becoming more like those of the cap-and-fill 
TABLE 5 | Baseline chemical properties of soils prior to application of fertilizer or compost but after establishment of urban cap-and-fill plots (May 2017).

\begin{tabular}{|c|c|c|c|c|c|c|c|c|c|}
\hline Treatment & $\mathrm{pH}$ & CEC & OM & $P$ & $\mathbf{K}$ & $\mathbf{S}$ & $\mathrm{Ca}$ & Mg & $\mathrm{Na}$ \\
\hline & & $\mathrm{meq} / 100 \mathrm{~g}$ & $\%$ & \multicolumn{6}{|c|}{$\mathbf{m g} / \mathbf{k g}$} \\
\hline Conventional & $6.2 \mathrm{~b}$ & $6.99 b$ & $3.55 b$ & 113.8b & $113.2 b$ & $13.5 b$ & $924.2 b$ & 99.0b & $26.8 b$ \\
\hline Compost-only & $6.2 b$ & $6.88 \mathrm{~b}$ & $3.45 b$ & $110.5 b$ & $94.0 \mathrm{~b}$ & $14.7 \mathrm{~b}$ & $930.2 b$ & $91.8 \mathrm{~b}$ & $30.2 b$ \\
\hline Precision organic & 6.3ab & $6.96 b$ & $3.81 b$ & $121.5 b$ & $116.0 b$ & $14.4 b$ & $932.0 \mathrm{~b}$ & 101.8b & $25.2 b$ \\
\hline Urban cap-and-fill & $6.4 a$ & $16.37 a$ & $9.18 \mathrm{a}$ & $258.8 a$ & 494.0a & $51.4 a$ & $2016.8 a$ & $307.5 a$ & $66.0 a$ \\
\hline SE & 0.05 & 0.87 & 0.23 & 13.19 & 28.85 & $\star \star$ & 127.10 & 6.44 & 3.52 \\
\hline
\end{tabular}

* Data were In transformed to equalize variances and backtransformed for presentation of means, but standard errors cannot be backtransformed.

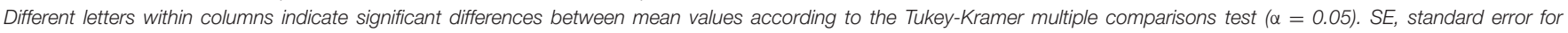
comparisons of treatment least squares means.

TABLE 6 | Compost properties, 2017-2019.

\begin{tabular}{|c|c|c|c|c|c|c|c|c|c|c|}
\hline \multirow[t]{2}{*}{ Year } & \multirow{2}{*}{$\begin{array}{c}\text { Bulk density } \\
\mathrm{g} / \mathrm{cm}^{3}\end{array}$} & \multirow[t]{2}{*}{$\mathrm{pH}$} & \multirow{2}{*}{$\begin{array}{c}\text { OM } \\
\%\end{array}$} & Total N & $P$ & $\mathbf{K}$ & $\mathbf{S}$ & $\mathrm{Ca}$ & $\mathbf{M g}$ & $\mathrm{Na}$ \\
\hline & & & & \multicolumn{6}{|c|}{ \% (Dry weight basis) } & $\mathrm{mg} / \mathrm{kg}$ \\
\hline 2017 & 0.74 & 7.7 & 44.3 & 0.9 & 0.30 & 0.56 & 0.15 & 1.40 & 0.25 & 310 \\
\hline 2018 & 0.68 & 7.3 & 39.7 & 1.3 & 0.34 & 0.55 & 0.15 & 1.17 & 0.23 & 366 \\
\hline 2019 & 0.68 & 7.3 & 40.9 & 1.5 & 0.40 & 0.68 & 0.17 & 1.32 & 0.25 & 283 \\
\hline
\end{tabular}

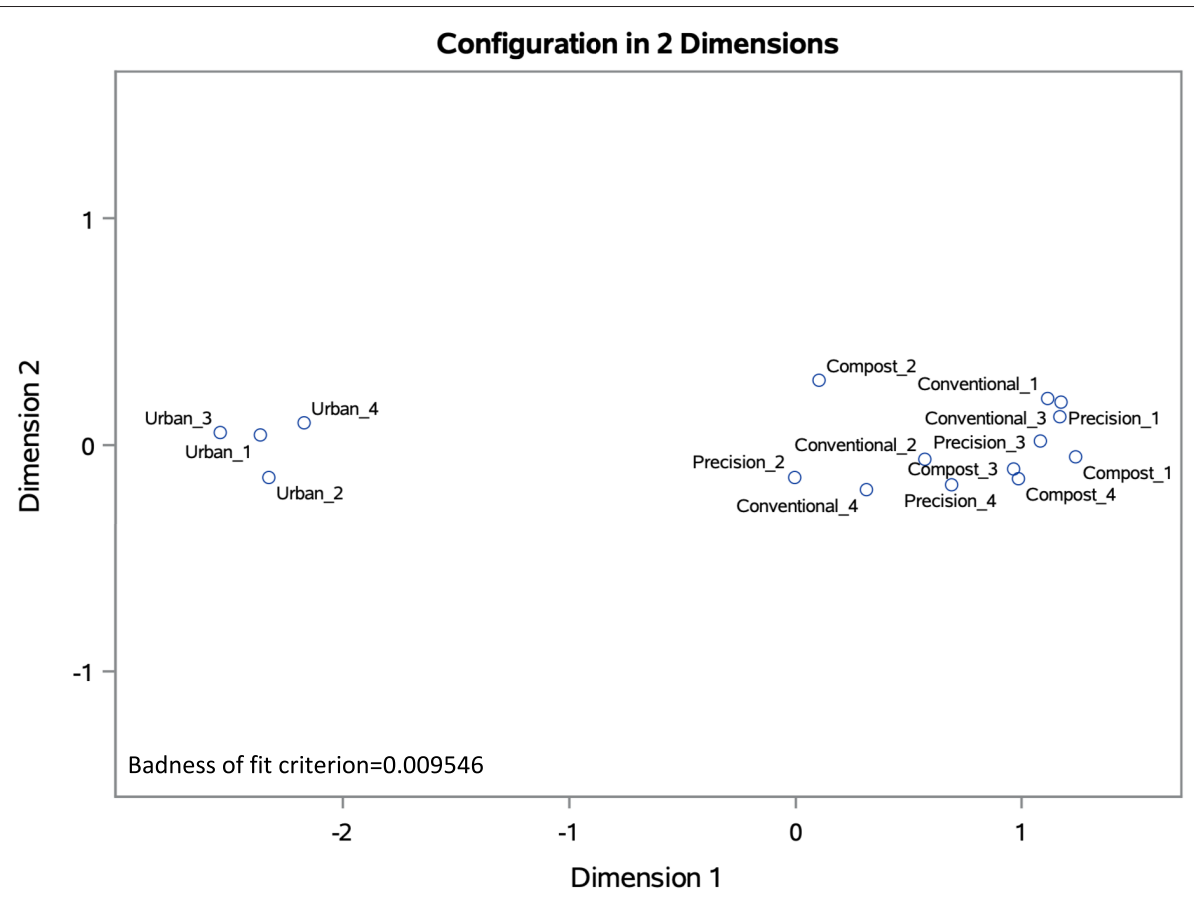

FIGURE 3 | NMDS ordination based on Bray-Curtis dissimilarity matrix for 2017 soil chemical characteristics (CEC, pH, OM, P, K, S, Ca, Mg, Na, Fe, Mn, Cu, Zn, and Al) of 16 experimental plots, four replicates per treatment.

plots due to 3 years of annual application of compost to plot beds (Figure 4).

Driven by the annual addition of compost, average values for $\mathrm{pH}, \mathrm{CEC}$, soil organic matter, phosphorus, potassium, sulfur, calcium, and magnesium had all increased significantly in the compost-only plots by 2019 compared to 2017 (Tables 7, 8).
Average potassium level in the compost-only treatment more than doubled over three growing seasons while average phosphorus increased a more modest $21.5 \%$. Phosphorus did not change significantly between 2017 and 2019 in any other treatment. In contrast, potassium levels declined significantly in all other treatments. The decline in potassium was particularly 


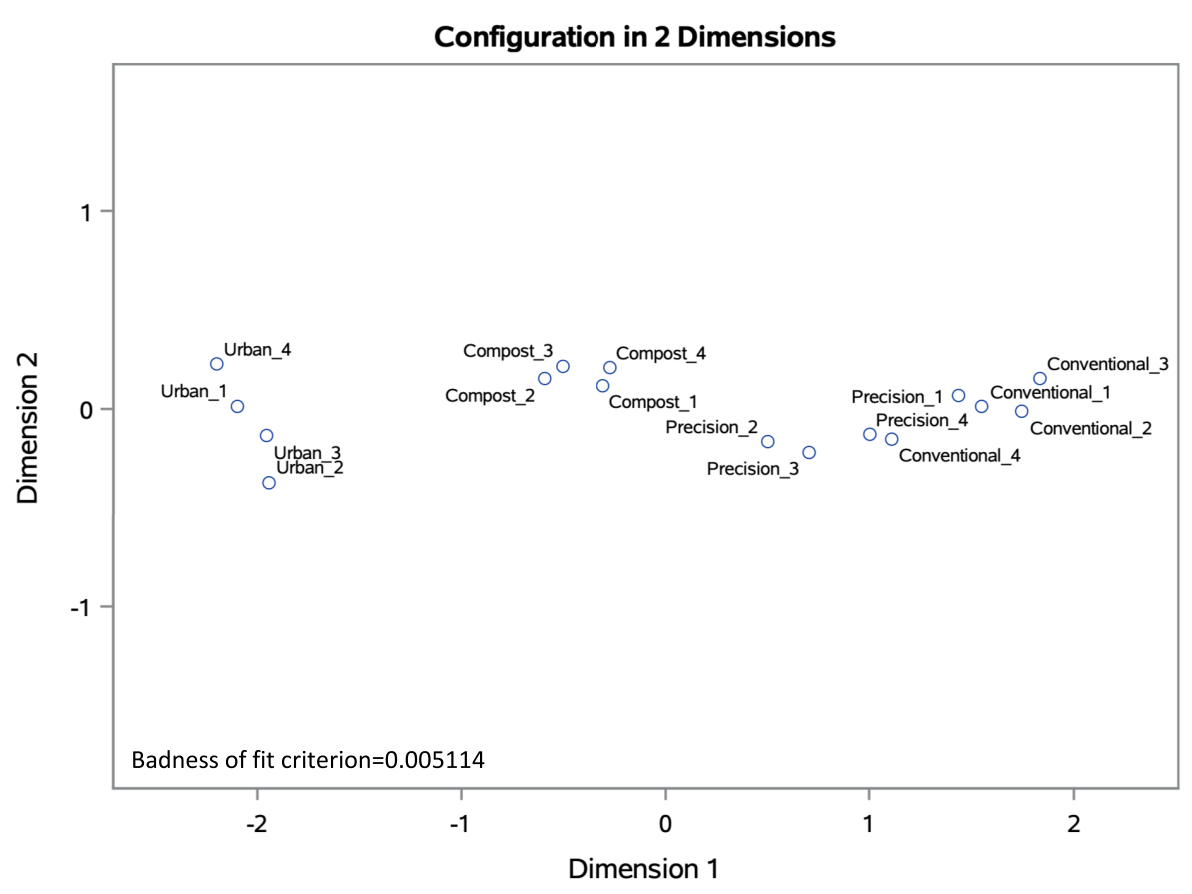

FIGURE 4 | NMDS ordination based on Bray-Curtis dissimilarity matrix for 2019 soil chemical characteristics (CEC, pH, OM, P, K, S, Ca, Mg, Na, Fe, Mn, Cu, Zn, and Al) of 16 experimental plots, four replicates per treatment.

TABLE 7 | Chemical properties of soils after three growing seasons (October 2019).

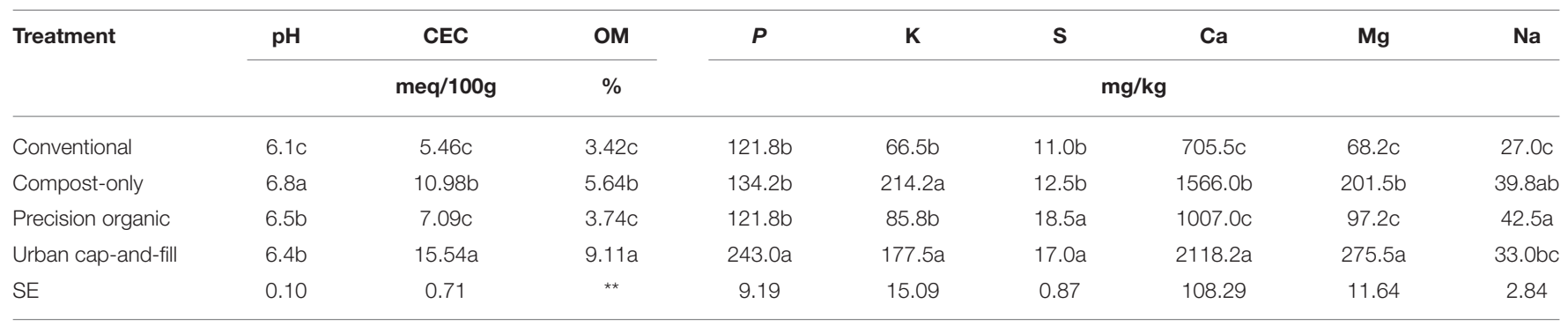

**Data were In transformed to equalize variances and backtransformed for presentation of means, but standard errors cannot be backtransformed. Note that variances could not be equalized for Na through transformation.

Different letters within columns indicate significant differences between mean values according to the Tukey-Kramer multiple comparisons test ( $\alpha=0.05)$. SE, standard error for comparisons of treatment least squares means.

steep in the case of the urban cap-and-fill plots, dropping from $494.0 \mathrm{mg} \mathrm{kg}^{-1}$ on average in 2017, after bed formation, to $177.5 \mathrm{mg} \mathrm{kg}^{-1}$ in October 2019.

No significant changes were observed in percent organic matter in the conventional, precision organic, or urban treatments over the 3-years study period despite tillage in the first two treatments and the lack of additions of exogenous organic matter in all three. Not surprisingly, the average level of permanganate oxidizable carbon (POXC) in the compost-only treatment in 2019 was significantly higher than in either the conventional or the precision organic treatment but significantly lower than the average POXC level of the urban treatment. Compost additions have a larger impact on POXC than does crop rotation or cover cropping, which were the same across all treatments (Hurisso et al., 2016).
Compost additions also drove changes in soil physical properties. In 2019, the bulk density of the compost-soil mix in the urban cap-and-fill beds was significantly lower, on average, than that of the soil in the conventional or precision organic plots and was lower than typical bulk densities for mineral soils (Table 9). After three yearly applications of compost, the bulk density of the soil in the compost-only plots was significantly lower than that of the other in-ground treatments-which were not significantly different from one another-and higher than but not significantly different from the bulk density of the compost-soil mix in the urban plots. Water infiltration rates in 2019 followed the same pattern (Table 9). They were lowest in the conventional and precision organic treatments (167 and $135 \mathrm{~mm} \mathrm{hr}^{-1}$, respectively), intermediate in the compost-only plots $(724 \mathrm{~mm}$ 
TABLE 8 | Changes in mean values for soil chemical properties between baseline (May 2017) and October 2019, after the third growing season.

\begin{tabular}{|c|c|c|c|c|c|c|c|c|c|}
\hline \multirow[t]{2}{*}{ Treatment } & \multirow[t]{2}{*}{$\mathrm{pH}$} & \multirow{2}{*}{$\begin{array}{c}\text { CEC } \\
\mathrm{meq} / 100 \mathrm{~g}\end{array}$} & \multirow{2}{*}{$\begin{array}{c}\text { OM } \\
\%\end{array}$} & $P$ & $\mathbf{K}$ & $\mathbf{S}$ & $\mathrm{Ca}$ & $\mathbf{M g}$ & $\mathrm{Na}$ \\
\hline & & & & \multicolumn{6}{|c|}{$\mathrm{mg} / \mathrm{kg}$} \\
\hline Conventional & -0.18 & -1.54 & -0.12 & 8.0 & $-46.8^{\star}$ & $-2.5^{\star}$ & -218.8 & $-30.8^{\star}$ & 0.2 \\
\hline Compost-only & $0.60^{\star}$ & $4.11^{\star}$ & $2.23^{*}$ & $23.8^{\star}$ & $120.3^{*}$ & $-2.2^{\star}$ & $635.8^{\star}$ & $109.8^{\star}$ & 9.5 \\
\hline Precision organic & 0.22 & 0.13 & -0.06 & 0.2 & $-30.2^{\star}$ & $4.0^{\star}$ & 75.0 & -4.5 & $17.2^{\star}$ \\
\hline Urban cap-and-fill & 0.00 & -0.82 & -0.04 & -15.8 & $-316.5^{\star}$ & $-36.2^{\star}$ & 101.5 & -32.00 & $-33.0^{*}$ \\
\hline
\end{tabular}

Asterisks indicate significant differences between 2017 and 2019 mean values according to paired sample t-tests ( $\alpha=0.05)$.

TABLE 9 | Soil physical properties and permanganate oxidizable carbon concentration after three growing seasons (October 2019).

\begin{tabular}{lccc}
\hline Treatment & $\begin{array}{c}\text { Bulk } \\
\text { density }\end{array}$ & $\begin{array}{c}\text { Water } \\
\text { infiltration }\end{array}$ & $\begin{array}{c}\text { Permanganate } \\
\text { oxidizable carbon }\end{array}$ \\
\cline { 2 - 4 } & $\mathbf{g} / \mathbf{c m}^{\mathbf{3}}$ & $\mathbf{m m} / \mathbf{h}$ & $\mathbf{~ m g / k g}$ \\
\hline $\begin{array}{l}\text { Conventional } \\
\text { Compost-only }\end{array}$ & $1.23 \mathrm{a}$ & $167 \mathrm{~b}$ & $313.30 \mathrm{c}$ \\
$\begin{array}{l}\text { Precision } \\
\text { organic }\end{array}$ & $1.06 \mathrm{~b}$ & $724 \mathrm{a}$ & $476.77 \mathrm{~b}$ \\
$\begin{array}{l}\text { Urban } \\
\text { cap-and-fill }\end{array}$ & $1.20 \mathrm{a}$ & $135 \mathrm{~b}$ & $361.92 \mathrm{c}$ \\
SE & $0.96 \mathrm{~b}$ & $1313 \mathrm{a}$ & $740.00 \mathrm{a}$ \\
& & & 31.49
\end{tabular}

**Data were cube transformed (bulk density) or square-root transformed (water infiltration) to equalize variances or to increase normality and backtransformed for presentation of means, but standard errors cannot be backtransformed.

Different letters within columns indicate significant differences between mean values according to the Tukey-Kramer multiple comparisons test. SE $=$ standard error for comparisons of treatment least squares means.

$\left.\mathrm{h}^{-1}\right)$, and highest in the urban-cap-and fill treatment $\left(1313 \mathrm{~mm} \mathrm{hr}^{-1}\right)$.

\section{DISCUSSION}

\section{Productivity}

Results from the first 3 years of data collection indicate that all four systems of intensive, small-scale, land-based production can be highly productive, with different potential environmental benefits and drawbacks. While total marketable food yields were relatively modest compared to those reported in the gray literature for biointensive agriculture-2.22-2.96 $\mathrm{kg} \mathrm{m}^{-2}$ averaged over 3 years in this study compared to $4.64 \mathrm{~kg} \mathrm{~m}^{-2}$ for the "low end" of biointensive production (Gittleman et al., 2012) - yields for most individual crops far exceeded regional averages based on reports from over 2,000 New England vegetable producers (USDA, 2019) and, for most crops and systems, national averages (Campbell-Nelson, 2020). Average total marketable food yields were also $55 \%$ to $107 \%$ higher than the average yield $\left(1.43 \mathrm{~kg} \mathrm{~m}^{-2}\right)$ reported by CoDyre et al. (2015) for an observational study of 50 backyard gardeners in Guelph, Ontario, Canada, which relied on self-reported yields.

In this study, marketable yield per square meter was calculated based on planted bed width plus the unplanted space between beds, which is comparable to the method used in agronomic studies. Failed plantings were also included in the calculation of total yield per square meter at the plot level. Unfortunately, comparisons with yields reported by observational studiesincluding CoDyre et al. (2015) - are fraught. Observational studies consistently fail to specify whether total area-including interbed spaces and failed plantings-or only productive area is used to calculate yield per area (Rabin et al., 2012). Similarly, they neglect to specify what is meant by "yield." In agronomic studies in the United States, vegetables and fruit are graded based on standards issued by the U.S. Department of Agriculture-as they were in this study-and yields are reported as either "marketable" or "total" yield. For example, USDA standards for No. 1 and Commercial kale-what would be considered to be marketable in an agronomic study-must be "free from decay and from damage caused by yellow or discolored leaves, seedstems, wilting, bud burn, freezing, dirt, disease, insects, or mechanical or other means" (Agricultural Marketing Service, 2005). A gardenercitizen scientist participating in an observational study, in contrast, might include kale with minor damage when reporting yields from their garden. This underspecification of "yield" makes it difficult to tell whether yields reported in observational studies are equivalent to those reported in agronomic studies. That said, "marketable" yield may not be the most appropriate measure of the productivity of urban agriculture sites, particularly those with the primary purpose of self-provisioning, but even those of a commercial character. Given concerns about food waste, consumers may perceive the purchase of "ugly" vegetables to be a responsible act, particularly if the vegetables are marketed as a sustainable option (van Giesen and de Hooge, 2019). In this context, "edible" yield may be a more appropriate measure and may, in fact, be what is being measured in observational studies. However, without consistent application of some mutual standard for measuring yield in urban agriculture, yields from agronomic studies cannot generally be compared to those from observational studies.

Total food yields in this study declined from year 1 to year 2 and then rebounded in year 3, underscoring the need for both experimental trials and observational studies with durations that adequately capture long-term system dynamics. Two years is the norm for many agronomic studies, while observational studies of urban agriculture seldom capture production data beyond a single growing season-a full year at most. Several factors may have contributed to the significant declines observed in this study in average yield across all in-ground treatments in 2018 compared to 2017. Lower total precipitation in June and 
July 2018 compared to 2017 (99.7 mm vs. $162.6 \mathrm{~mm}$ ) may have reduced yields in 2018 despite increased irrigation frequency with the drip irrigation system. Irrigation was scheduled based on the feel and appearance method (NRCS, 1998) in all three study years because this was deemed to be the method most accessible to small-scale growers. Measurement of soil moisture using tensiometers or other more objective methods and tracking of water use at the plot level would have helped to illuminate the possible relationship between water availability and yield in 2017 and 2018.

Differences in tillage between 2017 and 2018 may have also contributed to observed differences in total food yields. Full tillage of the site in 2017 prior to establishment of the experiment may have temporarily reduced soil bulk density and increased nitrogen availability. Subsequent consolidation and compaction of the mineral soil over the winter may have reduced soil porosity, root penetration, and nitrogen availability during the following growing season, reducing yields. While the conventional plot was tilled in 2018 with a rotary tiller, tillage depth was relatively shallow compared to initial tillage in 2017 with a moldboard plow. Sainju et al. (2000) found that, compared to moldboard plowing, no-till reduced tomato yields by $44 \%$ in 1 year of a 2 -years study, a yield loss almost identical to that observed in this study for tomato yields in in-ground treatments. With a much higher organic matter content, the growing medium in the cap-and-fill plots may not have been as vulnerable to the same processes of compaction hypothesized to have occurred in the mineral soils in the in-ground plots after initial tillage in 2017.

Particularly striking was the $86 \%$ increase in average marketable food yield for the compost-only treatment between 2018 and 2019 , from $1.47 \mathrm{~kg} \mathrm{~m}^{-2}$ to $2.74 \mathrm{~kg} \mathrm{~m}^{-2}$. This dramatic increase may reflect higher nutrient levels and higher rates of mineralization after 3 years of compost application and the eventual reestablishment of the soil microbial community responsible for mineralization following tillage in 2017. In conventional field crop systems, recovery of the microbial community may require 1-3 years following such tillage (Wortmann et al., 2008). At the same time, nutrient insufficiency may account for the lack of an increase in average food yield for the conventional treatment in 2019 compared to 2018. Soils in conventional plots were more vulnerable to nutrient leaching from very high levels of precipitation in June and July 2019 (301.4 $\mathrm{mm}$ total) because of the application of highly watersoluble synthetic fertilizers to these plots and the use a woven weed barrier rather than water-impermeable plastic film.

\section{Crop Mix}

Urban agriculture occurs within a specific social, cultural, economic, and political context which shapes farmers' and gardeners' motivations for growing food in the city. These motivations, in turn, influence the composition and diversity of crop plant assemblages (Taylor and Lovell, 2015; Pearsall et al., 2017; Taylor et al., 2017). Growers may prioritize the production of culturally-appropriate, high food-value, and/or high marketvalue crops. Experimental research can complement and inform efforts to model and design crop and crop-livestock assemblages that address urban growers' objectives, whether to maximize yield, profit, yield stability, sustainability, or other functions, such as ecological services (Ward and Symons, 2017).

Much as it might in a vernacular system, crop mix evolved over the 3-years data collection period, from six vegetable crops in 2017 to 15 vegetable and 5 cut flower crops in 2019, to better reflect the diversity of urban production systems (Clarke and Jenerette, 2015; Taylor and Lovell, 2015) and to increase system resilience through greater crop response diversity to environmental stressors (Gaudin et al., 2015). Though the original focus of the study was edible crops, the addition of cut flowers to the crop mix in 2018 was found to have a large, positive impact on the value of production at the system level because of the higher value per square meter of cut flowers compared to vegetable crops. Cut flower production, of course, does not directly address issues of food sovereignty and security. However, low income is a major determinant of food insecurity in the United States (Gundersen et al., 2011), and, as a lucrative side crop, the sale of cut flowers can help to subsidize food production in the urban market garden or farm or support the purchase of food from outside sources. For contaminated sites that would require costly remediation for food production, floriculture may be a more economically viable and socially acceptable option that generates income for urban growers (Manikas et al., 2019). Even in urban systems with the sole goal of self-provisioning, the addition of ornamental flowering plants to the food garden can have ecological and cultural benefits. Bee diversity and pollination services are correlated with floral diversity and abundance in urban neighborhoods (Lowenstein et al., 2014), and concentrating floral resources near sites of food production may be the best strategy for increasing pollination services to urban agriculture (Davis et al., 2017). In addition, food gardening in urban areas can be contentious when it transgresses residential landscape norms, e.g., the American front lawn. Incorporating flowering ornamentals into residential food gardens may increase their social acceptability much as floral enrichment enhances the perception of native plant landscapes (Nassauer, 1995).

\section{Soil Quality and Nutrient Dynamics}

Application of organic amendments in urban production systems can rapidly improve soil quality (J. Beniston and Lal, 2012; Small et al., 2017; Miernicki et al., 2018). In this study, three indicators of quality-bulk density, water infiltration rate, and permanganate oxidizable carbon, an indicator of soil microbial activity (Weil et al., 2003) and of stable pools of soil carbon (Hurisso et al., 2016) —were significantly higher in the compostonly treatment compared to the conventional and precision organic treatments after the gradual addition of yard waste compost over a 3-years period. Cation exchange capacity had also increased significantly in the compost-only treatment by October 2019 as had $\mathrm{pH}$ and levels of phosphorus, potassium, sulfur, calcium, and magnesium. After 3 years, soils in the compost-only plots were more similar to the 50:50 compost-soil mix in the urban cap-and-fill plots in terms of chemical and physical properties than they were to the soils in the conventional and precision organic plots. In 2017, compost-only plots were indistinguishable from the latter plots based on their chemical soil properties. 
Amendment with compost can be a key strategy for rehabilitating urban soils-which may be low in organic matter and nutrients, compacted, and contaminated-for food production (Beniston and Lal, 2012; Brown et al., 2016). Compost dilutes soil contaminants and may, depending on soil and compost characteristics, reduce the bioaccessibility of lead to food crops (Attanayake et al., 2014). By increasing crop growth, it also helps to reduce contaminant concentrations in crop biomass (Attanayake et al., 2014). Adding compost to urban agricultural soils with low levels of contamination is a potentially more cost-effective mitigative method than removal of the contaminated soil or capping and filling the site. In this study, annual application of compost in the compost-only treatment cost $\$ 0.52 \mathrm{~m}^{-2}$; the compost-soil mix used in the urban capand-fill treatment, in contrast, cost $\$ 10.14 \mathrm{~m}^{-2}$, almost 20 times as much.

Compost was surface applied each year to the compost-only plots. Little mixing of the compost with field soil occurred in 2018, when a broadfork was used to "crack" the soil after compost application, and even less in 2019, when the only mixing that occurred was due to soil disturbance from planting. Surface application of compost may not be as effective in reducing contaminant bioavailability or diluting contaminants as tilling the compost into the soil. However, as a mulch, compost has the benefit of reducing soil splashing from rain. Soil splashing and subsequent consumption of surface-contaminated plant parts may be a more significant pathway for lead ingestion from garden produce than plant absorption of soil lead (Brown et al., 2016).

In contrast to these benefits, use of compost in urban production systems may have negative agronomic and environmental consequences. Compost potentially increases soil water holding capacity through increased surface area, important in drier soil, and increased porosity, important in wetter soil (Cogger, 2005). Soil porosity increases at two scales, at the scale of capillary pores (30 to $50 \mu \mathrm{m}$ in diameter) and transmission pores $(50-500 \mu \mathrm{m}$ in diameter) (Pagliai et al., 1981; Cogger, 2005). An increase in porosity at the former scale potentially increases plant available water; increased porosity at the scale of transmission pores increases infiltration rates. Despite the apparent positive impact of compost on soil water holding capacity, the evidence for a corresponding increase in plant available water is equivocal (Cogger, 2005). Moreover, depending on the soil type and rate of compost application, the increase in transmission pores may lead to excessively high infiltration rates.

In this study, the average water infiltration rate for the urban cap-and-fill treatment was $1,313 \mathrm{~mm} \mathrm{~h}^{-1}, 8-10$ times the rate for the unamended treatments and almost twice as high as the average rate for the compost-only plots. Similarly high infiltration rates have been observed in experimental plots mimicking compost-amended urban production systems (Miernicki et al., 2018) and in situ, in home food gardens in Chicago (Taylor and Lovell, 2015). High rates of water infiltration due to reduced density and increased transmission pore space can exacerbate nutrient leaching and may increase water use (Miernicki et al., 2018). Water management is a key agronomic concern in urban agriculture due to constraints related to the availability, cost, and sustainability of irrigation water (Wortman and Lovell, 2013).
Growers may not have access to a water source or may rely on expensive municipal water to irrigate their crops. Leaching of nitrogen and phosphorus and nutrient loading of stormwater runoff are of particular environmental concern, but leaching of mobile nutrients in general from compost-amended soils also has agronomic implications. In this study, average potassium increased by $128 \%$ in the compost-only plots due to annual additions of compost but declined by $64 \%$ in the urban capand-fill treatment. While some urban farmers mine the compostsoil mixes in their cap-and-fill systems for nutrients, this study suggests that, over time, losses of potassium and other nutrients due to leaching and plant withdrawals-particularly in locales with high levels of precipitation, such as the study site-may lead to a need for potassium supplementation in the form of sidedressing during the growing season to maintain yields.

Repeated applications of compost in urban production systems to meet the nitrogen needs of crops can also lead to the accumulation of excessively high levels of phosphorus (Small et al., 2017, 2019). In its first 3 years, this project followed a common heuristic for community and market gardeners of adding $2.5 \mathrm{~cm}$ of compost to gardens beds annually. This practice resulted in a $21.5 \%$ increase in average soil phosphorus in the compost-only treatment over three growing seasons. While such heuristics reduce the cognitive load of nutrient management for urban growers, they are likely to have negative environmental consequences because of the resulting nutrient loading of stormwater runoff. These simplistic heuristics also waste nutrients and money. Urban agriculture service providers need to refine their nutrient management recommendations to growers based on soil tests, plot management history, local soil conditions, and compost properties.

Phosphorus accumulation can also be problematic in urban and rural systems relying on synthetic and organic fertilizers. Adherence to published recommendations for phosphorus application rates in the conventional and precision organic treatments resulted in average phosphorus levels in 2019 that were not significantly higher than base year levels, though they were still much higher than sufficiency levels. However, despite applications of potassium at recommended rates, potassium levels had declined significantly in the conventional and precision organic beds because of leaching and plant uptake, by $41.2 \%$ and $26.0 \%$, respectively. Precision organic beds may have retained more potassium in water insoluble forms such as greensand, a component of the solid organic fertilizer applied to the beds prior to planting. Use of a reusable woven geotextile as a weed barrier instead of disposable plastic film may have increased the vulnerability of soil nutrients to leaching in both systems. While regional guidelines recommend split applications only for nitrogen, they may also be needed for potassium to increase use efficiency (Römheld and Kirkby, 2010).

The sustainability of nutrient inputs in this project varied by system. Yard waste compost sourced from the Rhode Island Resource Recovery Center was the sole nutrient source for the compost-only and urban cap-and-fill plots, with the exception of a regionally-produced organic liquid fertilizer used at transplanting. While production of the compost requires expenditure of fossil fuels for transportation of compost stocks, 
turning of windrows, and compost delivery, it is arguably a more sustainable source of nutrients and organic matter than purchased, bagged compost from distant sources. The solid fertilizer used in the precision organic system is sourced from a regional manufacturer and consists of a wide range of ingredients, some of which may be from renewable regional sources, such as crab meal and fish meal, and others, including alfalfa, cocoa, cotton seed, peanut, and soybeans meals and greensand, phosphate rock, and natural nitrate of soda, which definitely are not. The conventional system uses synthetic mineral fertilizers from distant, non-renewable sources. Each of these nutrient inputs comes with tradeoffs which warrant further investigation beyond the scope of this paper. Compost is bulky to transport and more difficult to apply than synthetic or organic fertilizers. Urban gardeners and farmers may not have access to bulk supplies of compost or access to sufficient compost feed stocks to meet the nutrient needs of their crops. Nutrient availability is more difficult to predict for compost and organic fertilizers than for synthetic fertilizers, which are water soluble and are not dependent on mineralization by soil microbial communities. The cost of inputs used in the study varied greatly. The synthetic nitrogen from the urea used in the conventional system, for example, cost $\$ 4.35 \mathrm{~kg}^{-1}$ retail while the organic nitrogen from the solid fertilizer used in the precision organic system cost 5 times as much, $\$ 21.37 \mathrm{~kg}^{-1}$.

Cover cropping with cereal rye in all systems may have helped to scavenge and retain system nutrients at the end of each growing season, with additional benefits including reduced soil erosion and increased water infiltration through winter vegetative cover and maintenance of soil organic matter. Use of a leguminous cover crop such as hairy vetch instead of or in combination with cereal rye could reduce system reliance on external sources of nitrogen by providing a nitrogen credit to summer vegetable crops. However, cover cropping comes at a cost and is seldom practiced in urban agriculture. Maximizing the nitrogen credit from legumes and the contribution of cover crop biomass to soil organic matter requires delaying cover crop termination as late as possible in the spring, until at least late May in Rhode Island, followed by a 2 -weeks fallow period for the cover crop to decompose and, if rye is used, for allelopathic chemicals to degrade. While delayed planting may not be an obstacle to cover cropping for home gardeners, for market gardeners who benefit from the price premium associated with an early harvest it can be a competitive disadvantage.

Local recovery and use of nutrients from household waste, e.g., food waste, could reduce outside nutrient and organic matter inputs and increase system sustainability but is unlikely to meet crop demands. More radical strategies for nutrient recovery including composting of human feces and nutrient extraction from human urine could potentially meet crop needs. Wielemaker et al. (2018) estimate, in the context of the Dutch city of Rotterdam, that the nutrient outputs from such New Sanitation strategies could meet 100 percent of the phosphorus inputs and a significant portion of the nitrogen and organic matter needs of a sufficient area of urban agriculture to meet the fruit and vegetable requirements of the human population that is the source of the nutrients.

\section{Limitations}

The research has several limitations in terms of its generalizability. The project is being conducted not in situ but at the experiment station of a U.S. land grant university, in an open field without many of the socioeconomic and physical limitations found in urban environments, including limited light, anthropogenic soils, air pollution, and limited access to materials, equipment, and agronomic information. The project is evaluating the performance of a relatively narrow assemblage of commonly grown vegetable crops in a particular rotation and spatial arrangement. Many urban agriculturalists are immigrants who grow crops integral to traditional foodways. The cultural needs of these crops have seldom been assessed in traditional agronomic experiments let alone urban system trials such as that described in this article. Immigrant gardeners and farmers may also grow these crops in diverse systems not represented in agronomic research, such as the vertically-layered annual polyculture systems observed in the home gardens of Chinese-origin households in Chicago (Taylor and Lovell, 2015; Taylor et al., 2017). More observational and experimental research on these unique urban systems is required to establish normative production practices, including form and rates of nutrient inputs, tillage practices, and optimal plant species and varieties.

Only a single crop turn was grown in the system due to labor and time constraints, and the majority of crops were harvested over a relatively narrow 3-months period, from early July through the end of September. Use of low-cost season extension techniques such as low tunnels could expand the production window by a month or more in both the spring and summer, increasing yield per square meter on an annual basis. This phase of the project also did not evaluate the sustainability of material inputs to each system, track water use, or record labor inputs by system. In an observational study of 13 urban, smallscale organic production sites in Sydney, Australia McDougall et al. (2019) found that although these sites were twice as productive as Australian commercial vegetable farms, they were inefficient in their use of labor and materials. CoDyre et al. (2015) similarly found that backyard gardens in Ontario, Canada, were highly unsustainable economically, with the production of $\$ 4.58 \mathrm{USD} \mathrm{kg}^{-1}$ of food requiring $\$ 10.82 \mathrm{USD} \mathrm{kg}^{-1}$ in inputs, not including labor. Future phases of the project will address these limitations, by including spring and fall production cycles, analysis of input sustainability, and tracking of water use and labor inputs by system to create a fuller picture of the economic and environmental sustainability and labor productivity of each system.

\section{CONCLUSION}

While the potential contributions of small-scale, land-based urban production systems to enhancing food sovereignty in the United States have been dismissed by some (O'Sullivan et al., 2019), such systems have always been a part of urban life. In the aggregate, they already make a much larger contribution to urban food systems in the U.S. than the urban farms that have garnered 
so much attention and investment (Taylor and Lovell, 2012). Experimental research is needed to enhance the productivity, efficiency, and sustainability of these systems, and outreach is needed to communicate that research to urban growers. Paradigms for such research are underdeveloped, in part due to the lack of engagement of crop scientists in the scholarly and popular discourse on urban agriculture. This study is developing one possible framework for experimental research at a scale appropriate to urban agriculture. While not participatory in nature, its methods are based on close observation of vernacular urban production systems and a synthesis of the gray and scholarly literature on sustainable intensification. The research approach is adaptive. It recognizes that even small-scale gardens and farms are dynamic social-ecological systems. Rather than being an a priori expert on system dynamics, the researcher ismuch like a farmer or gardener-a humble student, constantly learning from the system. To quote Thomas Jefferson, "no occupation is so delightful to me as the culture of the earth, and no culture comparable to that of the garden. such a variety of subjects, some one always coming to perfection, the failure

\section{REFERENCES}

Ackerman, K. (2012). The Potential for Urban Agriculture in New York City: Growing Capacity, Food Security, and Green Infrastructure. New York, NY: Urban Design Lab at the Earth Institute Columbia University.

Agricultural Marketing Service (2005). United States Standards for Grades of Kale. Washington, DC. Retrieved from: https://www.ams.usda.gov/sites/default/ files/media/Kale_Standard\%5B1\%5D.pdf

Airriess, C. A., and Clawson, D. L. (1994). Vietnamese market gardens in New Orleans. Geogr. Rev. 84:16. doi: 10.2307/215778

Alkon, A. H., and Mares, T. M. (2012). Food sovereignty in US food movements: radical visions and neoliberal constraints. Agric. Hum. Values 29, 347-359. doi: 10.1007/s10460-012-9356-Z

Asen, P., Cynar, E., Downes, K., Gerlach, G., and Ma, A. (2014). Lots of Hope. Providence: City of Providence. Retrieved from: https://www.providenceri. gov/wp-content/uploads/2017/03/Lots- of-Hope-an- urban-agricultureassessment-with-the-City-of-Providence-March-2014.pdf

Attanayake, C. P., Hettiarachchi, G. M., Harms, A., Presley, D., Martin, S., and Pierzynski, G. M. (2014). Field evaluations on soil plant transfer of lead from an urban garden soil. J. Environ. Qual. 43, 475-487. doi: 10.2134/jeq2013.07.0273

Beck, T. B., Quigley, M. F., and Martin, J. F. (2001). Emergy evaluation of food production in urban residential landscapes. Urban Ecosyst. 5, 187-207. doi: 10.1023/A:1024093920660

Beniston, J., and Lal, R. (2012). "Improving soil quality for urban agriculture in the North central US," in Carbon Sequestration in Urban Ecosystems, eds R. Lal and B. Augustin (New York, NY: Springer), 279-313. doi: 10.1007/978-94-007-2366-5_15

Beniston, J. W., Lal, R., and Mercer, K. L. (2016). Assessing and managing soil quality for urban agriculture in a degraded vacant lot soil. Land Degrad. Dev. 27, 996-1006. doi: 10.1002/ldr.2342

Benke, K., and Tomkins, B. (2017). Future food-production systems: vertical farming and controlled-environment agriculture. Sust. Sci. Pract. Policy 13, 13-26. doi: 10.1080/15487733.2017.1394054

Boston Public Health Commission (2013). Soil Safety Guidelines for Commercial Urban Farming. Boston. Retrieved from: http://www.bostonplans.org/ getattachment/d37db157-5bc8-479c-aa73-dc462441519a

Brown, S. L., Chaney, R. L., and Hettiarachchi, G. M. (2016). Lead in urban soils: a real or perceived concern for urban agriculture? J. Environ. Qual. 45, 26-36. doi: 10.2134/jeq2015.07.0376

Buchthal, O., Nelson-Hurwitz, D., Hsu, L., Byers, M., and Banna, J. (2019). Identifying urban immigrant food-cultivation practices for culturally-tailored of one thing repaired by the success of another, and instead of one harvest a continued one thro' the year. under a total want of demand except for our family table I am still devoted to the garden. but tho' an old man, I am but a young gardener" (Oberg and Looney, 2008).

\section{DATA AVAILABILITY STATEMENT}

The datasets generated for this study are available on request to the corresponding author.

\section{AUTHOR CONTRIBUTIONS}

$\mathrm{JT}$ was responsible for all aspects of this research and manuscript.

\section{FUNDING}

This research was supported by a NIFA Hatch Grant, RI0018-H018, Building Regional Food Sovereignty through Urban Agriculture. garden-based nutrition programs. J. Immigr. Minor. Health 22, 778-785. doi: 10.1007/s10903-019-00952-z

Campbell-Nelson, K. (2020). New England Vegetable Management Guide (K. Campbell-Nelson Ed.). Amherst, MA: University of Massachusettts.

City of Chicago. (2020). City-Owned Land Inventory. Retrieved from: https://www. chicago.gov/city/en/depts/dcd/supp_info/city-owned_land_inventory.html

Clarke, L. W., and Jenerette, G. D. (2015). Biodiversity and direct ecosystem service regulation in the community gardens of Los Angeles, CA. Landsc. Ecol. 30, 637-653. doi: 10.1007/s10980-014-0143-7

CoDyre, M., Fraser, E. D., and Landman, K. (2015). How does your garden grow? An empirical evaluation of the costs and potential of urban gardening. Urban For. Urban Green. 14, 72-79. doi: 10.1016/j.ufug.2014.11.001

Cogger, C. G. (2005). Potential compost benefits for restoration of soils disturbed by urban development. Compost Sci. Util. 13, 243-251. doi: 10.1080/1065657X.2005.10702248

Coleman, E. (2018). The New Organic Grower: a Master's Manual of Tools and Techniques for the Home and Market. Gardener: Chelsea Green Publishing.

Davis, A. Y., Lonsdorf, E. V., Shierk, C. R., Matteson, K. C., Taylor, J. R., Lovell, S. T., et al. (2017). Enhancing pollination supply in an urban ecosystem through landscape modifications. Landsc. Urban Plan. 162, 157-166. doi: 10.1016/j.landurbplan.2017.02.011

Dewaelheyns, V., Rogge, E., and Gulinck, H. (2014). Putting domestic gardens on the agenda using empirical spatial data: the case of flanders. Appl. Geogr. 50, 132-143. doi: 10.1016/j.apgeog.2014.02.011

Donahue, B., Burke, J., Anderson, M., Beal, A., Kelly, T., Lapping, M., et al. (2014). A New England Food Vision. Durham, NH: Food Solutions New England, University of New Hampshire. Available online at: https://foodsolutionsne.org/ a-new-england-food-vision/

Edmondson, J. L., Davies, Z. G., McCormack, S. A., Gaston, K. J., and Leake, J. R. (2011). Are soils in urban ecosystems compacted? A citywide analysis. Biol. Lett. 7, 771-774. doi: 10.1098/rsbl.2011.0260

Fortier, J.-M., and Bilodeau, M. (2014). The Market Gardener: A Successful Grower's Handbook for Small-scale Organic Farming: New Society Publishers.

Garbach, K., Milder, J. C., DeClerck, F. A., Montenegro de Wit, M., Driscoll, L., and Gemmill-Herren, B. (2017). Examining multi-functionality for crop yield and ecosystem services in five systems of agroecological intensification. Int. J. Agric. Sust. 15, 11-28. doi: 10.1080/14735903.2016.1174810

Gaudin, A. C., Tolhurst, T. N., Ker, A. P., Janovicek, K., Tortora, C., Martin, R. C., et al. (2015). Increasing crop diversity mitigates weather variations and improves yield stability. PLoS ONE 10:113261. doi: 10.1371/journal.pone.0113261 
Gittleman, M., Jordan, K., and Brelsford, E. (2012). Using citizen science to quantify community garden crop yields. Cities Environ. (CATE). 5:4. doi: $10.15365 /$ cate. 5142012

Gregory, M. (2017). Enhancing Urban Food Production, Ecosystem Services, and Learning in New York City Gardens Through Cover Cropping And Participatory Action Research. PhD thesis. Ithaca, NY: Cornell University.

Gregory, M., Leslie, T., and Drinkwater, L. (2016). Agroecological and social characteristics of New York city community gardens: contributions to urban food security, ecosystem services, and environmental education. Urban Ecosyst. 19, 763-794. doi: 10.1007/s11252-015-0505-1

Gundersen, C., Kreider, B., and Pepper, J. (2011). The economics of food insecurity in the United States. Appl. Econ. Pers. Policy 33, 281-303. doi: $10.1093 /$ aepp/ppr022

Heynen, N., Kurtz, H. E., and Trauger, A. (2012). Food justice, hunger and the city. Geogr. Compass, 6, 304-311. doi: 10.1111/j.1749-8198.2012.00486.x

Hunter, C. M., Williamson, D. H., Pearson, M., Saikawa, E., Gribble, M. O., and Kegler, M. (2020). Safe community gardening practices: focus groups with garden leaders in Atlanta, Georgia. Local Environ. 25, 18-35. doi: 10.1080/13549839.2019.1688268

Hurisso, T. T., Culman, S. W., Horwath, W. R., Wade, J., Cass, D., Beniston, J. W., et al. (2016). Comparison of permanganate-oxidizable carbon and mineralizable carbon for assessment of organic matter stabilization and mineralization. Soil Sci. Soc. Am. J. 80, 1352-1364. doi: $10.2136 /$ sssaj2016.04.0106

Lithourgidis, A., Dordas, C., Damalas, C. A., and Vlachostergios, D. (2011). Annual intercrops: an alternative pathway for sustainable agriculture. Aust. J. Crop Sci. 5, 396-410.

Lovell, S. T. (2010). Multifunctional urban agriculture for sustainable land use planning in the United States. Sustainability 2, 2499-2522. doi: 10.3390/su2082499

Lowenstein, D. M., Matteson, K. C., Xiao, I., Silva, A. M., and Minor, E. S. (2014). Humans, bees, and pollination services in the city: the case of Chicago, IL (USA). Biodivers. Conserv. 23, 2857-2874. doi: 10.1007/s10531-014-0752-0

Manikas, I., Malindretos, G., and Abeliotis, K. (2019). Sustainable cities through alternative urban farming: the case of floriculture. J. Int. Food Agribus. Market. 1-17. doi: 10.1080/08974438.2019.1599762

McClintock, N., Cooper, J., and Khandeshi, S. (2013). Assessing the potential contribution of vacant land to urban vegetable production and consumption in Oakland, California. Landsc. Urban Plan. 111, 46-58. doi: 10.1016/j.landurbplan.2012.12.009

McDougall, R., Kristiansen, P., and Rader, R. (2019). Small-scale urban agriculture results in high yields but requires judicious management of inputs to achieve sustainability. Proc. Natl. Acad. Sci. U. S. A. 116, 129-134. doi: $10.1073 /$ pnas. 1809707115

McLean, E. (1982). "Soil pH and lime requirement," in Methods of Soil Analysis: Part 2 Chemical and Microbiological Properties 2nd Edn., ed A. L. Page (Wisconsin: ASA-SSA. Madison), 199-224. doi: 10.2134/agronmonogr9.2.2ed.c12

Mehlich, A. (1984). Mehlich 3 soil test extractant: a modification of mehlich 2 extractant. Commun. Soil Sci. Plant Anal. 15, 1409-1416. doi: 10.1080/00103628409367568

Miernicki, E. A., Lovell, S. T., and Wortman, S. E. (2018). Raised beds for vegetable production in urban agriculture. Urban Agric. Reg. Food Syst. 3, 1-10. doi: 10.2134/urbanag2018.06.0002

Moskal, B. T., and Berthrong, S. T. (2018). Novel soil barrier systems potentially protect urban growing beds from legacy soil contamination and improve soil health. Urban Agric. Reg. Food Syst. 3, 1-9. doi: 10.2134/urbanag2018.06.0003

NASS (2019). "Vegetables 2018 Summary," in United States Department of Agriculture National Agricultural Statistics Service (Washington, DC: National Agricultural Statistical Service of the US Department of Agriculture), 93.

Nassauer, J. I. (1995). Messy ecosystems, orderly frames. Landsc. J. 14, 161-170. doi: $10.3368 /$ lj.14.2.161

NRCS (1998). Estimating Soil Moisture by Feel and Appearance. Washington, DC, 1619.

NRCS (2020). Soil Survey Staff, Natural Resources Conservation Service, United States Department of Agriculture. Official Soil Series Descriptions. Available online at: https://www.nrcs.usda.gov/wps/portal/nrcs/detail/soils/ survey/geo/?cid=nrcs142p2_053587 (accessed January 15, 2020).
Oberg, B. B., and Looney, J. J. (2008). The Papers of Thomas Jefferson Digital Edition. Charlottesville: U of Virginia P, Rotunda.

O'Sullivan, C., Bonnett, G., McIntyre, C., Hochman, Z., and Wasson, A. (2019). Strategies to improve the productivity, product diversity and profitability of urban agriculture. Agric. Syst. 174, 133-144. doi: 10.1016/j.agsy.2019.05.007

Pagliai, M., Guidi, G., La Marca, M., Giachetti, M., and Lucamante, G. (1981). Effects of sewage sludges and composts on soil porosity and aggregation 1. J. Environ. Qual. 10, 556-561.

Pearsall, H., Gachuz, S., Rodriguez Sosa, M., Schmook, B., Wal, H., and Gracia, M. A. (2017). Urban community garden agrodiversity and cultural identity in Philadelphia, Pennsylvania, US. Geogr. Rev. 107, 476-495. doi: 10.1111/j.1931-0846.2016.12202.x

Pickett, S. T., Cadenasso, M. L., Grove, J. M., Boone, C. G., Groffman, P. M., Irwin, E., et al. (2011). Urban ecological systems: scientific foundations and a decade of progress. J. Environ. Manag. 92, 331-362. doi: 10.1016/j.jenvman.2010.08.022

Pollard, G., Roetman, P., and Ward, J. (2017). The case for citizen science in urban agriculture research. Future Food J. Food Agric. Soc. 5, 9-20.

Rabin, J., Zinati, G., and Nitzsche, P. (2012). Yield Expectations for Mixed Stand, Small-Scale Agriculture. New Brunswick, NJ: Rutgers University, New Jersey Agricultural Station.

Reeves, J., Cheng, Z., Kovach, J., Kleinhenz, M. D., and Grewal, P. S. (2014). Quantifying soil health and tomato crop productivity in urban community and market gardens. Urban Ecosyst. 17, 221-238. doi: 10.1007/s11252-013-0308-1

RI DEM. (2020). Overview of the Climate in Rhode Island. Available online at: http://www.dem.ri.gov/climate/climate-overview-ri.php

Römheld, V., and Kirkby, E. A. (2010). Research on potassium in agriculture: needs and prospects. Plant Soil 335, 155-180. doi: 10.1007/s11104-0100520-1

Ross, D., and Ketterings, Q. (2011). "Recommended methods for determining soil cation exchange capacity," in Recommended Soil Testing Procedures for the Northeastern United States, 3rd edn., ed D. E. Newark (Northeastern Regional Publication No. 493, Agricultural Experiment Station, University of Delaware), $62-70$.

Sainju, U. M., Singh, B. P., Rahman, S., and Reddy, V. (2000). Tillage, cover cropping, and nitrogen fertilization influence tomato yield and nitrogen uptake. HortScience 35, 217-221. doi: 10.21273/HORTSCI.35.2.217

Schulte, E., and Hopkins, B. (1996). Estimation of soil organic matter by weight loss-on-ignition. Soil Organ. Matter Anal. Interpret. 46, 21-31. doi: $10.2136 /$ sssaspecpub46.c3

Small, G., Shrestha, P., Metson, G. S., Polsky, K., Jimenez, I., and Kay, A. (2019). Excess phosphorus from compost applications in urban gardens creates potential pollution hotspots. Environ. Res. Commun. 1, 1-10. doi: 10.1088/2515-7620/ab3b8c

Small, G., Sisombath, B., Reuss, L., Henry, R., and Kay, A. (2017). Assessing how the ratio of barley mash to wood chips in compost affects rates of microbial processing and subsequent vegetable yield. Compost Sci. Util. 25, 272-281. doi: 10.1080/1065657X.2017.1329038

Taylor, J. R., and Lovell, S. T. (2012). Mapping public and private spaces of urban agriculture in Chicago through the analysis of high-resolution aerial images in Google Earth. Landsc. Urban Plan. 108, 57-70. doi: 10.1016/j.landurbplan.2012.08.001

Taylor, J. R., and Lovell, S. T. (2014). Urban home food gardens in the global north: research traditions and future directions. Agric. Hum. Values 31, 285-305. doi: 10.1007/s10460-013-9475-1

Taylor, J. R., and Lovell, S. T. (2015). Urban home gardens in the global north: a mixed methods study of ethnic and migrant home gardens in Chicago, IL. Renew. Agric. Food Syst. 30, 22-32. doi: 10.1017/S1742170514000180

Taylor, J. R., Lovell, S. T., Wortman, S. E., and Chan, M. (2017). Ecosystem services and tradeoffs in the home food gardens of African American, Chinese-origin and Mexican-origin households in Chicago, IL. Renew. Agric. Food Syst. 32, 69-86. doi: 10.1017/S174217051600003X

Tornaghi, C. (2017). Urban agriculture in the food-disabling city:(Re) defining urban food justice, reimagining a politics of empowerment. Antipode 49, 781-801. doi: 10.1111/anti.12291

USDA (2019). New England Vegetable and Strawberry Report, 2018 Crop. Concord, NH: USDA. Retrieved from: https://www.nass.usda.gov/Statistics_by_State/ New_England_includes/Publications/Current_News_Release/2019/eos2019_ vegetables.pdf 
van Giesen, R. I., and de Hooge, I. E. (2019). Too ugly, but I love its shape: reducing food waste of suboptimal products with authenticity (and sustainability) positioning. Food Qual Prefer. 75, 249-259. doi: 10.1016/j.foodqual.2019. 02.020

Via Campesina (2003). Food Sovereignty. Retrieved from: https://viacampesina. org/en/food-sovereignty/

Wagstaff, R. K., and Wortman, S. E. (2015). Crop physiological response across the Chicago metropolitan region: Developing recommendations for urban and peri-urban farmers in the North Central US. Renew. Agric. Food Syst. 30, 8-14. doi: $10.1017 /$ S174217051300046X

Ward, J., and Symons, J. (2017). Optimising crop selection for small urban food gardens in dry climates. Horticulturae 3:33. doi: 10.3390/horticulturae 3020033

Weil, R. R., Islam, K. R., Stine, M. A., Gruver, J. B., and Samson-Liebig, S, E. (2003). Estimating active carbon for soil quality assessment: a simplified method for laboratory and field use. Am. J. Alter. Agric. 18, 3-17. doi: 10.1079/AJAA2003003

Wezel, A., Casagrande, M., Celette, F., Vian, J.-F., Ferrer, A., and Peigné, J. (2014). Agroecological practices for sustainable agriculture. A review. Agron. Sust. Dev. 34, 1-20. doi: 10.1007/s13593-013-0180-7

Wielemaker, R. C., Weijma, J., and Zeeman, G. (2018). Harvest to harvest: recovering nutrients with New Sanitation systems for reuse in Urban agriculture. Resourc. Conserv. Recycl 128, 426-437. doi: 10.1016/j.resconrec.2016.09.015

Witzling, L., Wander, M., and Phillips, E. (2011). Testing and educating on urban soil lead: a case of Chicago community gardens. J. Agric. Food Syst. Community Dev. 1, 167-185. doi: 10.5304/jafscd.2010.012.015
Woods, M. E., Ata, R., Teitel, Z., Arachchige, N. M., Yang, Y., Raychaba, B. E., et al (2016). Crop diversity and plant-plant interactions in urban allotment gardens. Renew. Agric. Food Syst. 31, 540-549. doi: 10.1017/S1742170515000472

Wortman, S. E., and Lovell, S. T. (2013). Environmental challenges threatening the growth of urban agriculture in the United States. J. Environ. Qual. 42, 1283-1294. doi: 10.2134/jeq2013.01.0031

Wortmann, C., Quincke, J., Drijber, R., Mamo, M., and Franti, T. (2008). Soil microbial community change and recovery after one-time tillage of continuous no-till. Agron. J. 100, 1681-1686. doi: 10.2134/agronj2007.0317

Yaro, R. D., and Carbonell, A. (2018). "Reinventing megalopolis: the northeast megaregion," in Smart Growth in a Changing World, ed J. Barnett (New York, NY: Routledge), 77-93. doi: 10.4324/9781351179621-6

Yu, Y., Stomph, T.-J., Makowski, D., and van der Werf, W. (2015). Temporal niche differentiation increases the land equivalent ratio of annual intercrops: a meta-analysis. Field Crops Res. 184, 133-144. doi: 10.1016/j.fcr.2015. 09.010

Conflict of Interest: The author declares that the research was conducted in the absence of any commercial or financial relationships that could be construed as a potential conflict of interest.

Copyright (c) 2020 Taylor. This is an open-access article distributed under the terms of the Creative Commons Attribution License (CC BY). The use, distribution or reproduction in other forums is permitted, provided the original author(s) and the copyright owner(s) are credited and that the original publication in this journal is cited, in accordance with accepted academic practice. No use, distribution or reproduction is permitted which does not comply with these terms. 